Research, part of a Special Feature on Programme on Ecosystem Change and Society (PECS): Knowledge for Sustainable Stewardship of Social-ecological Systems

\title{
A holistic approach to studying social-ecological systems and its application to southern Transylvania
}

\author{
Jan Hanspach $^{1}$, Tibor Hartel ${ }^{2}$, Andra I. Milcu ${ }^{1}$, Friederike Mikulcak ${ }^{1}$, Ine Dorresteijn ${ }^{1}$, Jacqueline Loos $^{1}{ }^{\text {, Henrik von Wehrden }}{ }^{3,4}$, \\ $\underline{\text { Tobias Kuemmerle }}^{5}$, David Abson $^{6}$, Anikó Kovács-Hostyánszki $^{7}$, András Báldi $^{7}$ and Joern Fischer $^{1}$
}

\begin{abstract}
Global change presents risks and opportunities for social-ecological systems worldwide. Key challenges for sustainability science are to identify plausible future changes in social-ecological systems and find ways to reach socially and environmentally desirable conditions. In this context, regional-scale studies are important, but to date, many such studies have focused on a narrow set of issues or applied a narrow set of tools. Here, we present a holistic approach to work through the complexity posed by cross-scale interactions, spatial heterogeneity, and multiple uncertainties facing regional social-ecological systems. Our approach is spatially explicit and involves assessments of social conditions and natural capital bundles, social-ecological system dynamics, and current development trends. The resulting understanding is used in combination with scenario planning to map how current development trends might be amplified or dampened in the future. We illustrate this approach via a detailed case study in southern Transylvania, Romania, one of Europe's most significant biocultural refugia. Our goal was to understand current social-ecological dynamics and assess risks and opportunities for sustainable development. Our findings show that historical events have strongly shaped current conditions and current development trends in southern Transylvania. Moreover, although external drivers (including EU policies) set the general direction of regional development trajectories, local factors, including education, leadership, and the presence of bridging organizations, can enhance or counteract their effects. Our holistic approach was useful for generating an in-depth understanding of a regional social-ecological system and could be transferred to other parts of the world.
\end{abstract}

Key Words: ecosystem service bundles; landscape sustainability science; Programme on Ecosystem Change and Society; regional scale; Romania; scenario planning

\section{INTRODUCTION}

The Anthropocene is characterized by unprecedented, rapid, and uncertain socioeconomic and environmental changes (Schröter et al. 2005, Rockström et al. 2009). A major challenge for sustainability science is to identify plausible changes that may occur in the future of a given system, and identify ways to reach or maintain socially and environmentally desirable system states (Gibson 2006). The concept of social-ecological systems (also termed human-environment systems or coupled human and natural systems) highlights that people and nature are interconnected, with their inter-relationships constantly coevolving, thus making them analytically inseparable (Folke 2006, Liu et al. 2007). Although social-ecological systems are characterized by dynamic complexity, many are fundamentally shaped by a relatively small number of variables (Walker et al. 2006). Identifying and investigating the relationships between such key variables reduces the often seemingly intractable complexity of the systems studied, allowing useful scientific and policy insights.

Landscape and regional scales (spanning hundreds to thousands of square kilometers) have been suggested as particularly useful for studying social-ecological systems (Liu et al. 2007, Carpenter et al. 2012). Regions are also often the scale at which policy is implemented, and they represent institutional, social, and physical "spaces" that are tangible and meaningful for humans (Brown and Raymond 2007, Angelstam et al. 2013). However, most research to date has investigated future development pathways either at the global scale or at very fine scales (e.g., individual villages) while intermediate scales have been neglected
(Rounsevell et al. 2012). Many studies that have been conducted at landscape or regional scales have focused on relatively narrow sets of issues or applied a relatively narrow set of methodological tools.

Here, we present a holistic analytical approach to study the risks and opportunities facing social-ecological systems. This approach considers cross-scale interactions, spatial heterogeneity, and multiple uncertainties (Fig. 1), and could be usefully applied to a wide range of social-ecological systems worldwide. It systematically combines several tools, namely the documentation of system dynamics (Allison and Hobbs 2004, Liu et al. 2007), scenario planning (Enfors et al. 2008, Palomo et al. 2011), and spatial mapping (Anderson et al. 2009, Nelson et al. 2009). The documentation of system dynamics involves identifying the most important variables in a given system and evaluating (qualitatively or quantitatively) how they interact with one another (Walker and Salt 2006, Meadows 2009). It provides an understanding of the current state of a system and its functional relationships, but not necessarily of its plausible future pathways or people's aspirations to alter the system. For this reason, we combine our assessment of systems dynamics with scenario planning, a foresight methodology specifically used to envision future pathways of a given system (Peterson et al. 2003, Biggs et al. 2010). Scenario planning provides a structured approach to identify different plausible developments for the future, typically to evaluate the possible outcomes of alternative management options (e.g., Henrichs et al. 2010, Palomo et al. 2011). Finally, because socialecological changes in any given region are typically spatially heterogeneous, spatially explicit mapping offers additional

${ }^{1}$ Faculty of Sustainability, Leuphana University Lüneburg, ${ }^{2}$ Department of Environmental Sciences, Sapientia University, ${ }^{3}$ Institute of Ecology, Faculty of Sustainability \& Centre for Methods, Leuphana University Lüneburg, ${ }^{4}$ Research Institute of Wildlife Ecology, Austria, ${ }^{5}$ Geography Department, Humboldt-Universität zu Berlin, ${ }^{6}$ FuturES Research Center, Leuphana University Lüneburg, ${ }^{7}$ MTA Centre for Ecological Research 
Fig. 1. Schematic summary of the five main methodological steps followed (A-E). Combining an understanding of local conditions (A) with an understanding of regional dynamics (B) resulted in spatially explicit maps depicting current social-ecological development trends in different locations (C). Maps of development trends, combined with regional scenarios (D), were then used to generate spatially explicit maps of social-ecological conditions under the different scenarios (E).

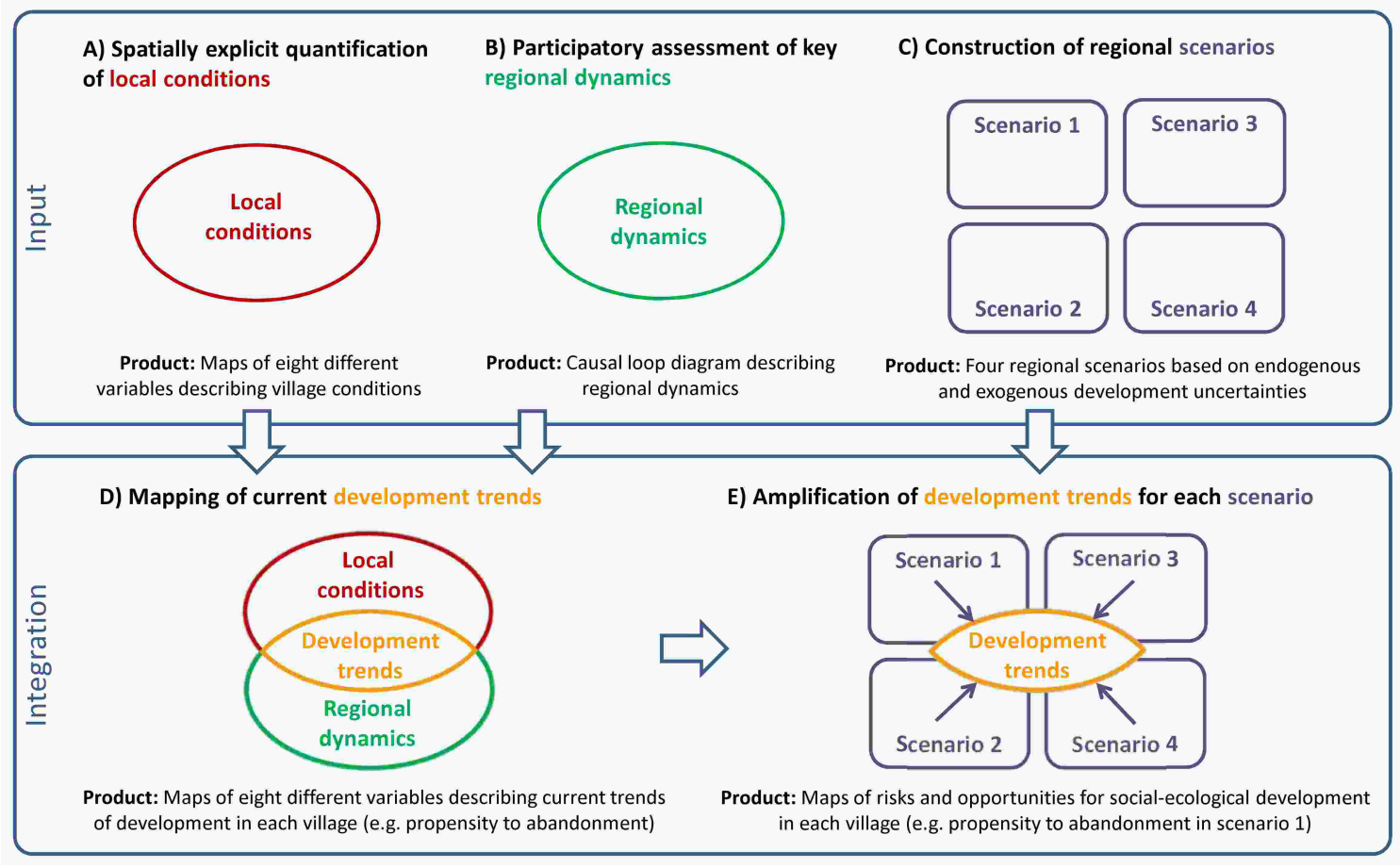

benefits to regional case studies (Santelmann et al. 2004, Polasky et al. 2005, Nelson et al. 2009). Spatial variation can arise for numerous reasons. Both biophysical and socioeconomic conditions may vary across a region, and different drivers of change may be more or less pronounced in different locations (Baumann et al. 2011). Spatial mapping can help to elicit spatial variation and can highlight trade-offs and synergies among different system properties (such as ecosystem services; see Raudsepp-Hearne et al. 2010, Qiu and Turner 2013). Our overall approach, which combines these different tools (Fig. 1), is integrative and participatory because it considers both ecological and social aspects of the study system and because it involves consultation of and collaboration with local stakeholders.

To illustrate our approach, we present a detailed application to the region of southern Transylvania, Romania (Fig. 2). This region is used primarily for semi-subsistence, small-scale farming, and traditional land-use practices have sustained a flora and fauna that is unusually rich compared to other parts of Europe (Akeroyd 2007, Akeroyd and Page 2011). With its ethnic Romanians, Hungarians, Roma, and Saxons, it also embraces an unusually high diversity of cultures and traditions. However, through a series of recent changes, the region now has become one of Europe's most vulnerable frontiers of global change. The collapse of Romania's communist regime in 1989, in combination with the general breakdown of socialism in Eastern Europe, led to a substantial reorganization of institutions, economies, and societies, with far-reaching social-ecological consequences,
Fig. 2. Map of the study area in southern Transylvania, Romania, in the foothills of the Carpathian Mountains.

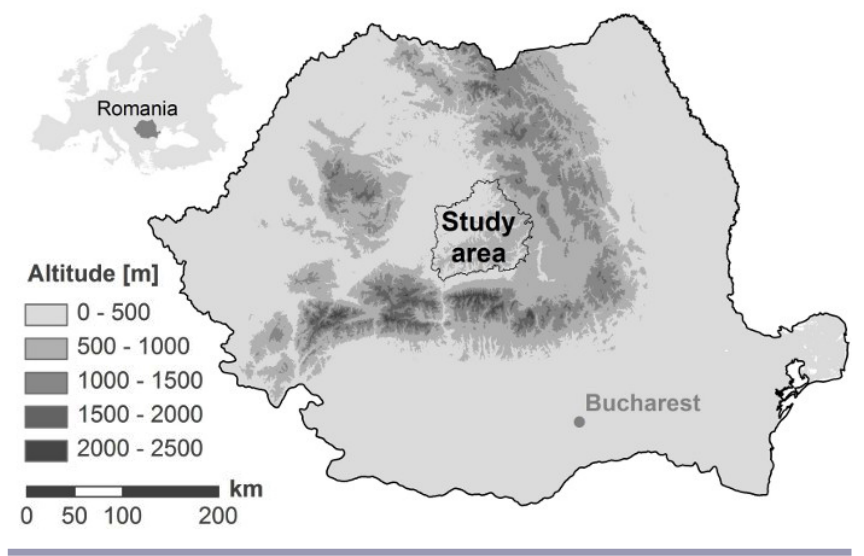

including mass emigration (especially of ethnic Saxons, but also Romanians), farmland abandonment, and changing land-use patterns stemming from the privatization of land (Ioffe et al. 2004, Lerman et al. 2004, Rozelle and Swinnen 2004, Kuemmerle et al. 2009, Baumann et al. 2011). Moreover, Romania's 2007 accession to the European Union (EU), as well as ongoing globalization, continue to alter the socioeconomic and institutional fabric of 
the region, threatening both social and natural capital (Dobre 2009, Gorton et al. 2009, Mikulcak et al. 2013). Navigating the rapid and fundamental changes taking place in southern Transylvania poses major challenges to local stakeholders and provides both risks and opportunities for sustainable development (Fischer et al. 2012b).

To investigate these risks and opportunities, we first classified and spatially mapped local conditions of several hundred villages in the study area in terms of their natural capital, social and demographic characteristics, terrain, and connectivity via roads to major towns. Second, we performed participatory workshops with local organizations and individual experts to develop causal loop diagrams describing regional social-ecological system dynamics. Third, we combined our understanding of local conditions and regional dynamics into maps depicting current social-ecological development trends. Fourth, we developed four contrasting, plausible future scenarios for a 30-yr horizon, again drawing on local expertise. Finally, we combined the maps of current development trends with the scenarios to ascertain where within the study region existing trends would be amplified or dampened under different scenarios. These methods are exemplified here using an in-depth regional case study, but the general approach could be used to explore plausible future development pathways in regional social-ecological systems worldwide.

\section{METHODS}

\section{Study area}

The study was conducted in central Romania and covered an area of $7440 \mathrm{~km}^{2}$ at altitudes between 230 and $1100 \mathrm{~m}$ above sea level (Fig. 2) that is characterized by a mosaic of different land-cover types ( $28 \%$ forest, $24 \%$ pasture, and $37 \%$ arable land). Historically, most of the study area was shaped in terms of culture and land use by ethnic Saxons, immigrants from Western Europe who first settled Transylvania 800 years ago. However, most Saxons left the area after the collapse of communism in 1989. Today, the area is predominantly populated by Romanian, Hungarian, and Roma ethnicities.

\section{Local conditions}

We used the village as the basic unit of analysis because it represents a useful scale for the analysis of social-ecological systems in rural landscapes (Angelstam et al. 2003). The study area contained 448 villages. Because no official village borders were available, we delineated the area belonging to a given village using a cost-distance algorithm that allocated each pixel to the village with the lowest travel cost to this pixel (slope-penalized distance, implemented in ArcGIS). We defined the area thus associated with a given village as a village catchment (Appendix 1). This algorithm performed well because most villages were located in valleys, and a screening of results revealed that many boundaries of village catchments closely matched the borders of communes (administrative units containing four villages on average).

We applied a two-fold approach to characterize the biophysical and socio-demographic conditions in the villages. First, to obtain an in-depth understanding, we assessed an extensive set of local conditions for a subset of 30 villages (Appendix 1) and then generalized our findings to all 448 villages in the study area. The
30 villages were selected randomly from all villages, but were stratified to cover: (1) the full gradient in terrain ruggedness, measured as the variation in altitude within a given catchment; and (2) conservation status, i.e., no protection, protection under the EU Birds Directive, protection under the EU Habitats Directive. We estimated ecological and socio-demographic variables for the 30 selected villages.

Variables describing the natural capital of a given village catchment were based on the proportions of arable land, pasture, orchards, scenic beauty, utility as hunting area, carbon stocks, farmland biodiversity, and pollinator abundance (for details see Appendix 1). Socio-demographic data, derived from communelevel statistics, were: total population size, proportions of the main ethnic groups, unemployment rate, net migration levels, and the number of pupils relative to the total population in a given commune (Appendix 1). We intended no judgment by the use of ethnic group as a variable to describe socio-demographic conditions, and we emphasize that possible relationships with other socio-demographic variables (see below) indicate correlations, not causalities. Moreover, no alternative sociodemographic data were readily available for the whole study area.

The main gradients and groups of the local characteristics in the 30 villages were analyzed using cluster analysis (Wards clustering based on Euclidean distances) and principal components analysis on standardized data (zero mean, unit variance), separately for natural capital and socio-demographic data (Fig. 3, Appendix 1). Based on the initial in-depth analysis of a subset of 30 villages (Fig. 3, Appendix 1), we concluded that the proportion of the main land-cover types (arable, pasture, forest) provided a good indication of the natural capital bundles in a given village, and that the proportion of Hungarians and Roma could be used to summarize the main socio-demographic characteristics of a given village. Therefore, we used these variables to summarize local conditions in all 448 villages (Fig. 4). Finally, we estimated village area, terrain ruggedness, and isolation from the nearest town for all villages in the study area. While we acknowledge that our assessment of local conditions was a "snapshot" of the dynamic social-ecological conditions, we believe it was nevertheless a useful means of identifying broad social-ecological differences within the study area.

\section{Regional dynamics and scenarios}

The assessment of regional dynamics and the development of scenarios were based on participatory workshops with local organizations and key individuals representing social, environmental, and economic interests. They included members of all relevant ethnic groups, political parties, churches, and schools, as well as local police officers and organizations concerned with nature conservation, regional development, forestry, agriculture, and tourism. Based on our expertise in the region, groups were subjectively chosen to be broadly representative of different interest groups within the study area. To give all groups equal opportunities to express their views, we first held individual workshops with each stakeholder group, and only later conducted joint workshops, which were led by a professional facilitator (see below). From all groups, we received positive feedback about the quality of the workshops.

Scenario planning workshops broadly followed the suggestions by Henrichs et al. (2010). Workshops were led by us, and 
Fig. 3. Statistical classification of the 30 focal villages according to their natural capital assets. Upper panel: Three village types were derived from agglomerative cluster analysis (Wards method on Euclidean distances; agglomerative coefficient: 0.86 ). Central plot: Principal component analysis of relevant village characteristics (explained variance of axis 1 is $50 \%$, axis 2 is $18 \%$ ). Flower diagrams: Extent to which different types of natural capital are represented in the different villages. Three main groups of villages are apparent and relate to dominant land use: forest, yellow; arable, blue; pasture, red.

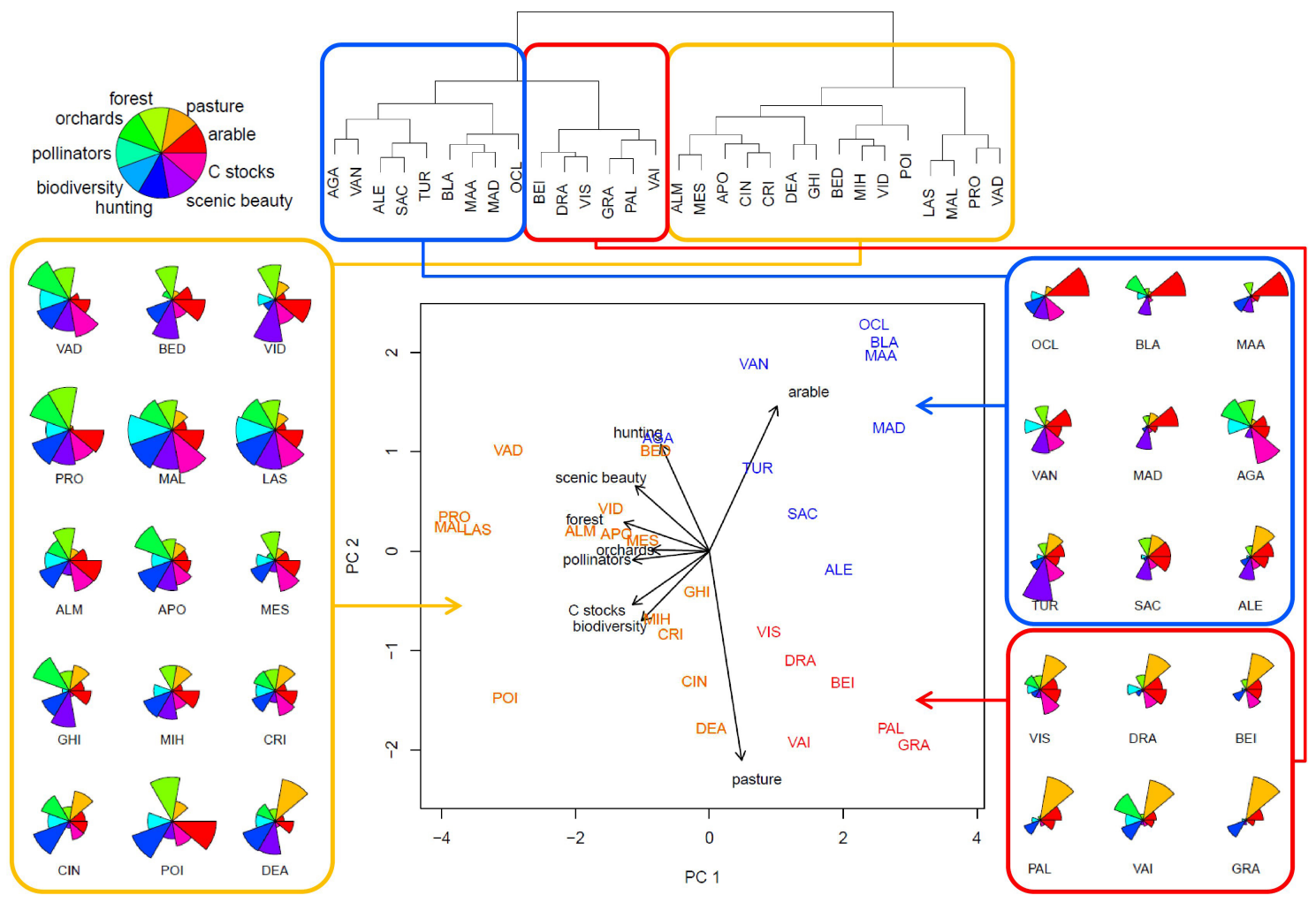

stakeholders provided input via consultations and a review of the final products. In a first round of workshops (summer 2012), we separately met representatives of 16 local organizations to collate their understandings of changes in the region, as well as of socialecological system dynamics and key uncertainties. Organizations were asked to list the main social, economic, and ecological changes in the past and present, as well as potential changes in the future. We asked participants to focus on the most important changes and to indicate how they influenced one another, leading to the development of causal effect chains and draft causal loop diagrams. We also asked which possible changes were within and beyond their control, and how uncertain they were (Daconto and Sherpa 2010).

Based on the insights obtained from these initial workshops, we developed a single, integrative causal loop diagram describing regional systems dynamics (Fig. 5). This was achieved by combining cause-and-effect chains consistently identified by stakeholders into a single draft diagram. For the purposes of this diagram, we used the term "social capital" to summarize broadly key interrelated themes such as trust, shared norms, and the involvement in social networks. We are aware of various conceptions and criticisms of social capital (Putnam et al. 1993), but believe that this term adequately captured an appropriate amount of detail for our purposes.
Drawing once again on insights obtained in the initial stakeholder workshops, we developed internally consistent scenario logics by distinguishing between two main axes of potential uncertainties, namely exogenous versus endogenous uncertainties (Fig. 6). Within the space characterized by these two axes, we developed four plausible storylines describing sequences of social, ecological, and economic changes. In a second set of two separate workshops, we presented our draft integrative causal loop diagram and drafts of our scenario logics and narratives to the local organizations initially consulted and to some additional local experts who were interested in participating (nine organizations and three individual experts in total; December 2012). Based on the (positive) feedback obtained in this second set of workshops, we refined and finalized our causal loop diagram and scenario narratives and considered these as final products representing local expert consensus (Fig. 7).

Notably, scenario planning inherently focuses on endpoints, that is, the outcomes of possible social-ecological developments in the future. In this way, it leaves space for complementary methods such as backcasting or adaptation, which provide a normative framework and tools to decide which development would be most desirable and which steps should be taken to achieve certain future conditions (Dreborg 1996, Wise et al. 2014). 
Fig. 4. Maps describing local conditions in the village catchments with respect to selected variables. The classes "very low" to "very high" correspond to quintiles of the raw data.
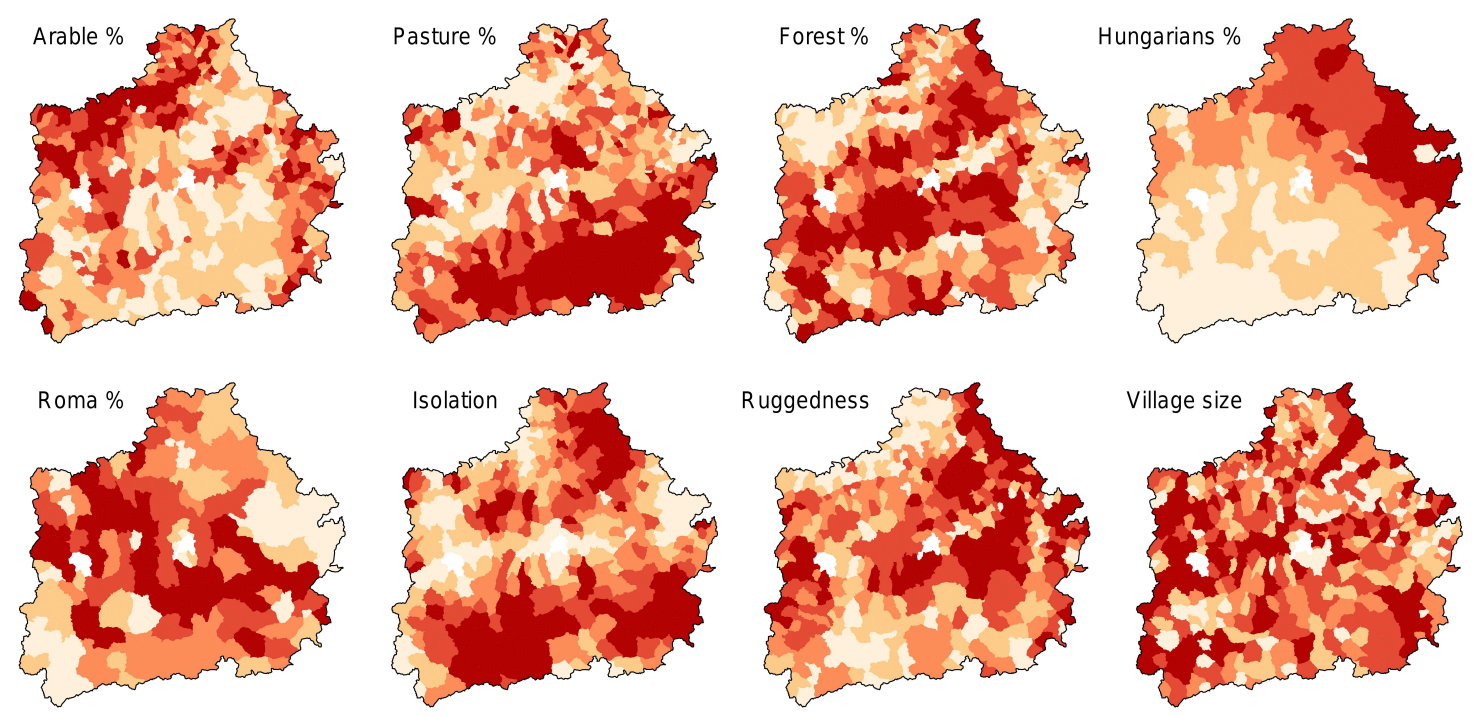

$\square$ very low $\square$ low $\square$ medium $\square$ high $\quad \square$ very high

\section{Mapping social-ecological development trends}

We combined our knowledge about local conditions and regional systems dynamics by mapping current perceived trends of socialecological development for each village. During the initial workshops, we asked participants how changes in eight key variables (boxes in the causal loop diagram; see Fig. 5) would relate to one or more of eight different village characteristics. All consistent and reasonable answers were collated into a table via a simple scoring system (Appendix 1). For example, local experts typically perceived that the trend for abandonment was more likely in small, remote, hilly villages with a lot of Roma, and less likely in large, flat, well connected villages. For a given village, we then translated these subjective expert assessments into a positive $(+1)$ or negative $(-1)$ score and summed the scores obtained for each characteristic. The possible range of summed scores for a given village and a given variable was between -5 (a trend toward a particular change is highly unlikely) and +5 (a trend toward a particular change is highly likely). In combination, the resulting values represent the social-ecological development trends of a given village and were mapped to visualize patterns across the study area (Fig. 8, left column).

\section{Scenario maps}

Finally, we combined regional maps of development trends with changes taking place in the four different scenarios to describe the possible amplification or dampening of current trends in the future. Drawing on the scenario narratives, we subjectively rated the main changes relating to the eight variables under each scenario by adding scores ranging between -3 (strong dampening) and +3 (strong amplification) to the existing scores of socialecological development trends (Appendix 1). For example, a village with a moderate trend toward abandonment (e.g., a score of 2) would, under a scenario with fairly strong dampening of that trend (e.g., a score of -2 ), result in a scenario-specific land
Fig. 5. Causal loop diagram summarizing the dynamics of the regional social-ecological system. Red arrows, enhancing effects; blue arrows, reducing effects. Variables in boxes were considered by local stakeholders to vary spatially in response to locally variable socioeconomic or ecological characteristics. Although the same system dynamics apply to the entire region, intensities vary through space. The spatially heterogeneous variables depicted in boxes were used to inform socialecological development trends and scenario maps (see Fig. 6). $\mathrm{R} 1$ refers to the reinforcing feedback loop around local economy, poverty, conflicts, and social capital.

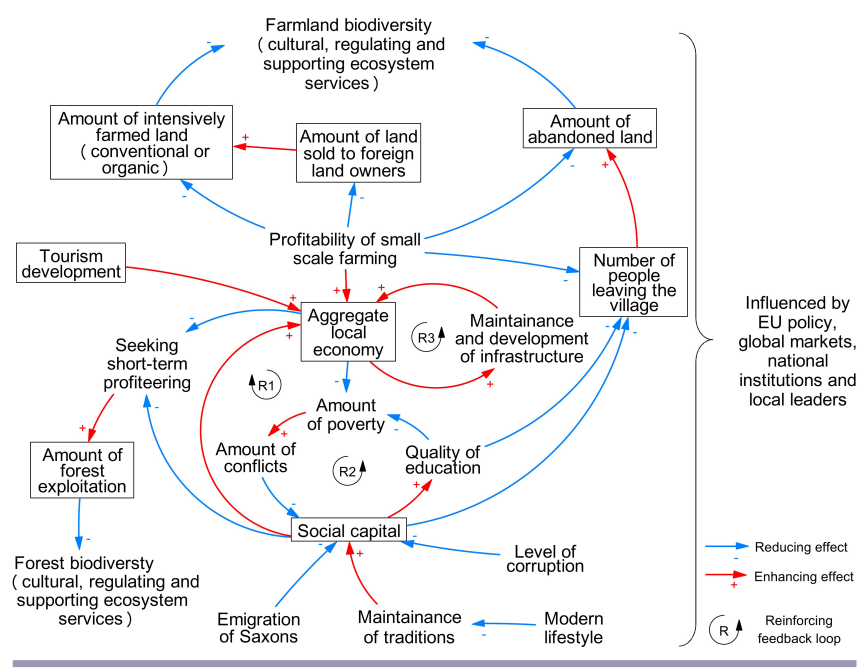


Fig. 6. Scenario matrix highlighting four plausible alternative futures arising from the combinations of two axes describing key uncertainties regarding future development. The horizontal axis relates to exogenous uncertainties, namely, whether national and supra-national policies emphasize economic development or environmental sustainability. The vertical axis relates to uncertainties within the study area, namely, whether local communities are able to capitalize on social and economic opportunities that may arise in the future.

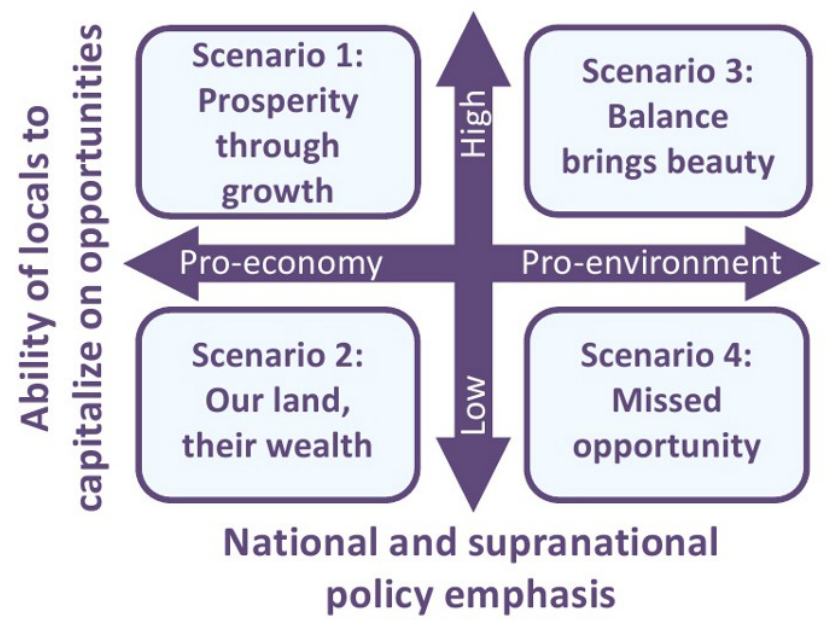

abandonment score of 0 (i.e., no trend toward abandonment). Notably, this simple scoring system served as a heuristic tool to compare relative differences between villages and scenarios, and not as an absolute indication of specific levels of any given variable.

\section{RESULTS}

\section{Local conditions}

With respect to ecological conditions, villages could be classified by the relative proportions of major land covers, namely arable land, pasture, or forest (Fig. 3, Appendix 1). Villages with a high proportion of forest had high carbon stocks, high scenic beauty, and a high abundance of pollinators. Villages with a high proportion of pasture also tended to contain high carbon stocks and supported high farmland biodiversity. Villages with a lot of arable land were characterized by low stocks of natural capital, with the exception of high capacity to generate agricultural products. We found that dominant land cover varied considerably across the entire study area (Fig. 4). The proportion of arable land (median: $57 \%$, interquartile range: $39-83 \%$ ) was relatively high in the northwestern parts of the study area, whereas the proportion of pastures $(21 \%, 13-30 \%)$ was relatively high in the southern parts. Villages with extensive areas of forest $(23 \%, 14$ $36 \%$ ) tended to be located in the central parts of the study area.

With respect to socio-demographic conditions, Romanians were the most abundant ethnic group on average (median: $57 \%$, interquartile range: $2.2-82 \%$ ), especially in the southwestern part of the study area. Hungarians $(12 \%, 1.2-73 \%)$ constituted the major ethnic group in the northeast, and the proportion of Roma
Fig. 7. Visual representations of key features of the four scenarios in terms of their effects on the landscape. Proeconomy settings lead to landscape simplification (scenarios 1 and 2), whereas pro-environment settings are likely to maintain landscape heterogeneity (including some land abandonment in scenario 4). Social and economic development for local villagers is particularly poor in scenario 2 , and to a lesser extent in scenario 4; in both cases, villages are physically isolated from international farm businesses.
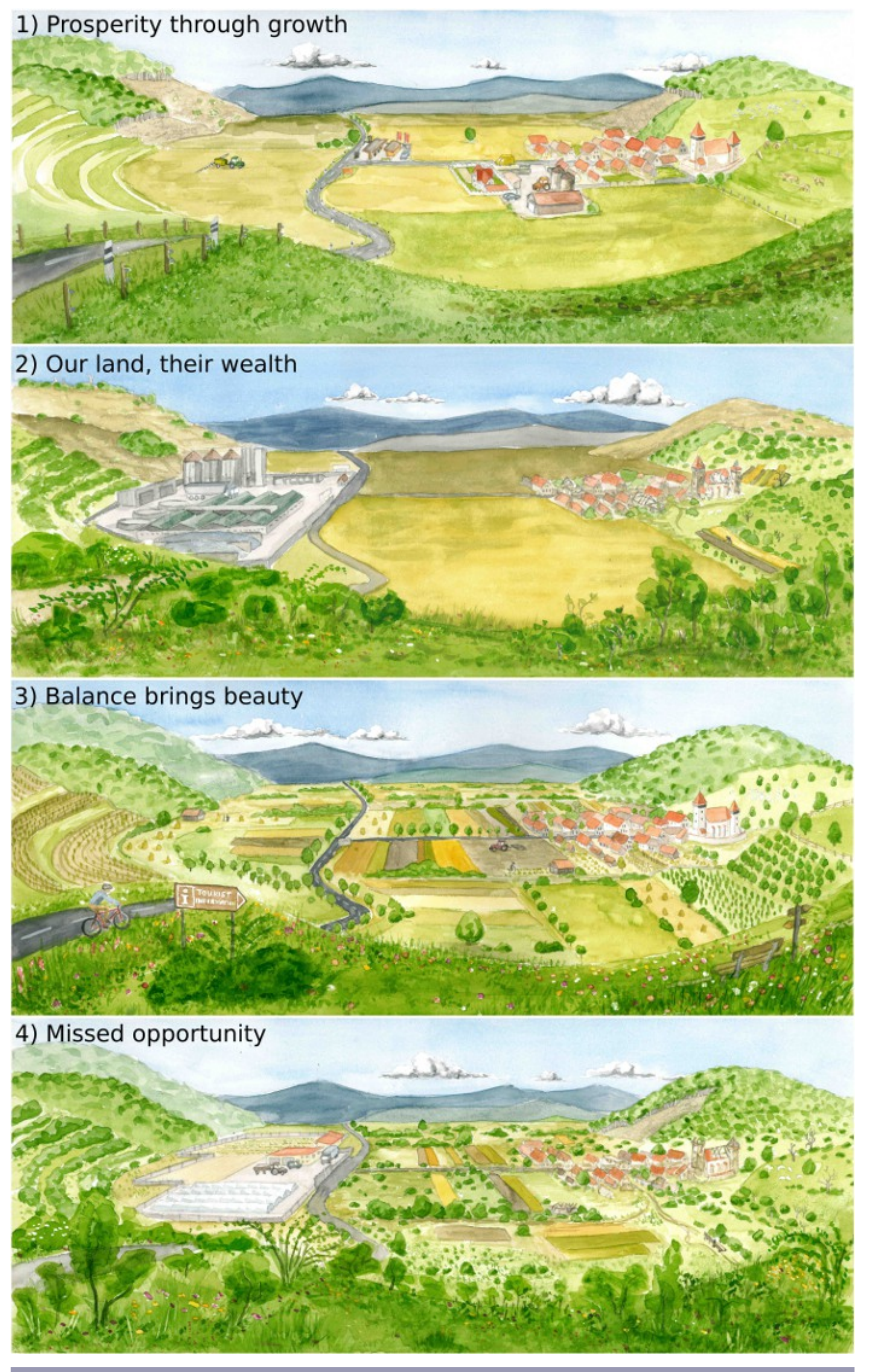

$(9.5 \%, 3.7-18 \%)$ was highest in the historically Saxon area in the center of the study area. The analysis of data from the random subset of 30 villages showed that the proportion of Hungarians was positively related to immigration and negatively to emigration. Communes with relatively higher proportions of Roma tended to have many school pupils and a high unemployment rate (Appendix 1). Isolation from towns (median: $24 \mathrm{~min}$, interquartile range: $15-33 \mathrm{~min}$ ) was highest in the south and in parts of the north of the study area. Terrain ruggedness was highest in the central and northeastern parts $(49 \%, 43-58 \%)$. No clear spatial pattern was apparent with respect to village area (median: 57 ha, interquartile range: $39-83 \mathrm{ha}$ ). 
Fig. 8. Maps of current social-ecological development trends (left column) and social-ecological risks and opportunities under the four scenarios (other columns).

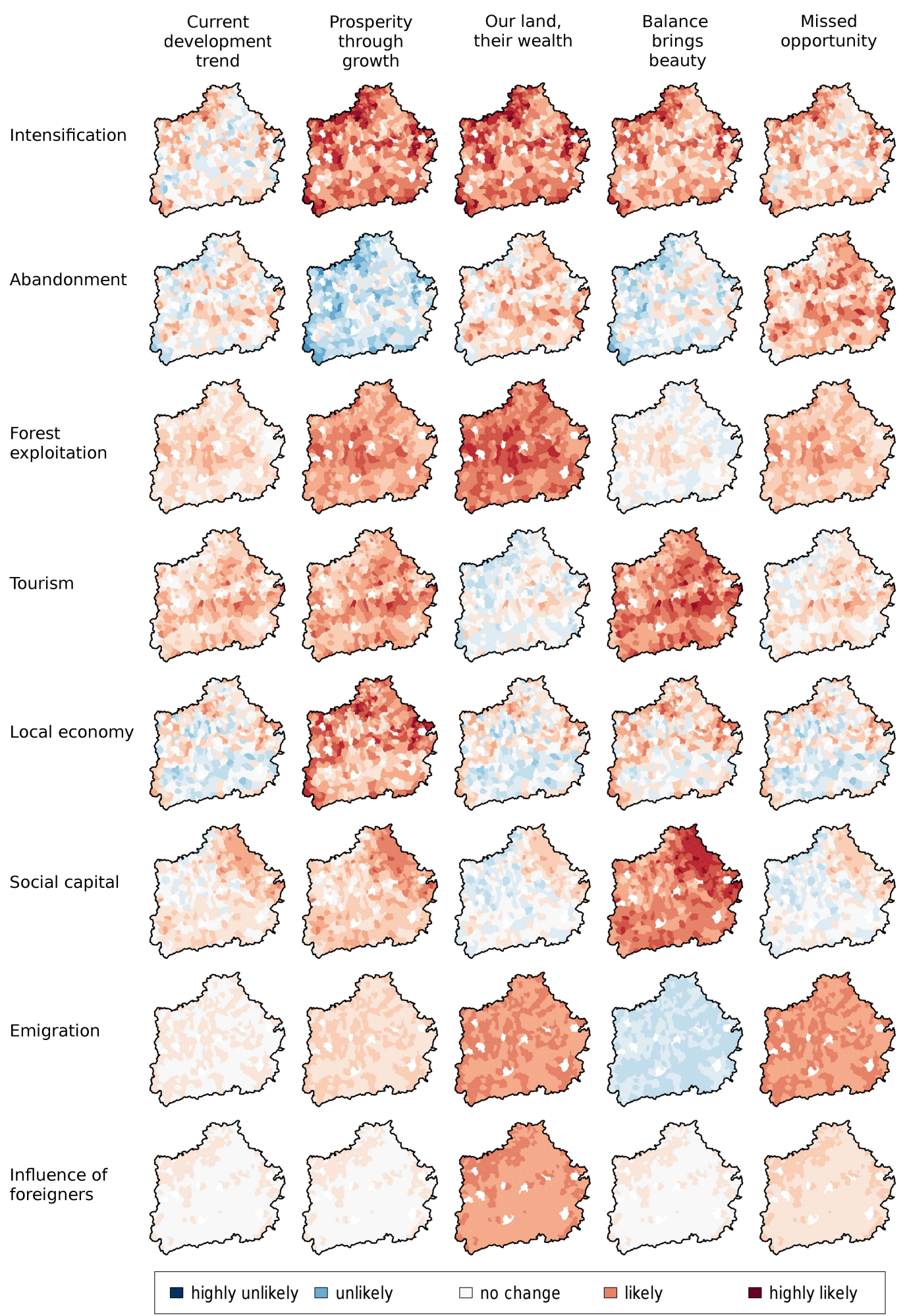




\section{Regional dynamics}

Participatory workshops led to a single consensus causal loop diagram (Fig. 5). Results suggest a strong link between the economy of a given village and its social capital. The low profitability of traditional small-scale farming was widely seen as a key reason for poor economic conditions, which in turn caused emigration (especially among the young) and land abandonment. Alternatives to small-scale farming (as raised by stakeholders) were the conversion to larger, more intensive farms controlled by either wealthy locals or by foreign investors. Larger-scale, more capital-intensive farms could practice conventional or organic agriculture.

Poor economic conditions were seen to be reinforced by poor infrastructure and low social capital (R3 and R1 in Fig. 5, respectively), whereas tourism development was suggested as having the potential to positively influence the local economy. The desire for economic development could also lead to short-term profiteering, causing the unsustainable exploitation of some resources (e.g., forests). The communist regime and its collapse were believed to have fundamentally shaped the social-ecological system. Most importantly, the collapse of communism was associated with high levels of corruption and the near complete exodus of Saxons after 1990 (mostly via emigration to Germany). These changes, combined with a shift toward a more modern lifestyle, appear to have reduced social capital in the region. Stakeholders reported a reinforcing feedback loop around poverty, conflict, low social capital, and poor education (R2 in Fig. 5), which caused rural emigration to Romanian towns or cities or to Western Europe. Finally, the dual processes of farmland intensification in some areas and abandonment in others was believed to lead both to a decrease in traditional smallscale farming and consequently was seen to affect negatively farmland biodiversity, as well as cultural, regulating, and supporting ecosystem services. Similarly, forest exploitation for timber and firewood was considered a threat to forest biodiversity and the ecosystem services provided by forests.

\section{Social-ecological development trends}

Maps of social-ecological development trends show strong spatial variation for most variables assessed (Fig. 8, left column). For example, trends toward farmland intensification, abandonment, tourism development, and a strong village economy were likely in some villages, but less likely in other villages. Other variables (e.g., role of foreigners, emigration, forest exploitation) had less pronounced variation in social-ecological development trends. Farmland intensification and abandonment were correlated and showed an inverse pattern, that is, the trend toward abandonment was reported to be likely where intensification was reported to be unlikely, and vice versa.

\section{Regional scenarios}

Participatory workshops suggested that key uncertainties regarding future development could be categorized along two axes, namely exogenous versus endogenous uncertainty (Fig. 6). The exogenous (horizontal) axis showed that national and supranational policy settings might either favor a narrow vision of economic growth or more holistically foster environmentally sustainable development. The endogenous (vertical) axis represents the extent to which local communities are able to capitalize on opportunities provided by policies or markets (e.g., because of strong or weak local leadership, or high or low corruption). Within the resulting space, together with stakeholders, we developed four different scenarios describing alternative plausible futures over a $30-y r$ time horizon beginning in 2012 (Figs. 6 and 7; see Appendix 1 for full scenario narratives).

In the first scenario, "prosperity through growth", small-scale farming is replaced by intensified, larger-scale, conventional agriculture. Forests are exploited where profitable, and tourism is restricted to the entertainment sector (e.g., fun parks). Economic development is driven by local people, and consequently, people are wealthier than 30 years previously. These developments cause losses in farmland and forest biodiversity, as well as the deterioration of regulating, supporting, and cultural ecosystem services.

In the second scenario, "our land, their wealth", land use is also intensified and also causes the loss of regulating, supporting, and cultural services. However, economic development is driven by foreign investors, and consequently, few locals benefit from it. The gap between rich and poor widens. Crime and conflicts are frequent, including between ethnic groups. People leave their villages for Romanian towns or Western Europe, and most farmland that is unprofitable for foreign companies is abandoned. Due to the difficult socioeconomic conditions and a highly disturbed landscape, tourism all but vanishes from Transylvania.

The third scenario, "balance brings beauty", describes a future in which locals are organized and able to capitalize on high national and international demand for organic agricultural products. Sustainable use of resources coexists with intensified land use via modern organic farming methods. Vibrant cultural tourism and eco-tourism stabilize people's incomes from the agricultural sector. Although few people are financially wealthy, economic and social inequalities are reduced and community spirit is high. Cultural and natural capital is valued and actively maintained.

In the fourth scenario, "missed opportunity", locals are unable to capitalize on the opportunities provided by a pro-environment policy setting. Instead, foreign companies set up modern organic farms in the region, exploiting easy access to cheap land and labor. Semi-subsistence farming as it has been practiced for many decades is ongoing in the villages, while forests are exploited for firewood and sometimes logged illegally. Most locals are poor, and those who are able to, leave the area. Corruption, crime, and conflict are common. Farmland biodiversity experiences moderate decreases due to intensification in some areas and abandonment in others.

\section{Scenario maps}

The combination of current social-ecological trends with the four scenarios resulted in a set of "scenario maps", which give a spatial representation of how key variables in the regional system are amplified or dampened under each scenario (Fig. 8). For example, under current trends, tourism development was deemed most likely in villages with high scenic beauty, and the overall likelihood of tourism development was highest in the scenario "balance brings beauty". By contrast, even in villages with high scenic beauty, tourism development would face severe challenges in the scenario "our land, their wealth" because of unfavorable conditions for tourism development throughout the region. Similar contrasts were apparent for several development trends. 
Land-use intensification took place across all scenarios, but was least pronounced in the scenario "missed opportunity". By contrast, major changes in several other variables were pronounced only in single scenarios (e.g., forest exploitation in "our land, their wealth"; tourism development, high social capital, and low emigration in "balance brings beauty").

\section{DISCUSSION}

We illustrated a structured five-step approach to explore holistically the development trajectories of social-ecological systems; the approach considers multiple sources of uncertainty, spatial heterogeneity, and cross-scale interactions. With respect to the study area, this approach effectively highlighted both risks and opportunities for sustainable development. Based on our analysis, we see the main opportunities for the future of southern Transylvania in maintaining and carefully capitalizing on its high natural capital and cultural heritage, for example, through promoting biodiversity conservation and eco-cultural tourism. Major risks relate to the careless exploitation of natural capital and the possible deterioration of socioeconomic conditions driven by political decisions that favor short-term interests at the expense of building social capital.

In the following sections, we further discuss particular risks and opportunities for future development in southern Transylvania and use these to substantiate three general postulates, namely that trajectories of social-ecological systems are (1) shaped by their specific historical contexts, (2) influenced by external drivers, and (3) modified by internal dynamics. These three postulates, as well as our holistic analytical approach, are also likely to be relevant to other social-ecological systems.

\section{Historical contingency shapes social-ecological dynamics}

The history of a given social-ecological system fundamentally influences its development trajectory (Dearing et al. 2010, Costanza et al. 2012). In our results, this is most prominently shown in the causal loop diagram of the regional system dynamics (Fig. 5), as well as in the maps of current development trends (Fig. 8). Although it might appear trivial to note that history shapes the current nature of social-ecological systems and that current conditions constrain development options for the future, such an understanding is missing from many conceptual frameworks used to analyze land-use options (Fischer et al. 2008).

The role of historical legacies is readily apparent in settings that have experienced major shocks, such as did the study system in southern Transylvania. Similarly to other Eastern European countries, Romania's social fabric is still suffering from the aftermath of an era of systematic oppression during communism. The country has a long history of communities being exploited by a relatively few influential individuals (Spendzharova and Vachudova 2012), and widespread corruption continues to take a heavy toll on social capital, eroding trust and general community engagement (Ristei 2010, Hartel et al. 2014). Many communities find themselves in social or social-ecological poverty traps (Platt 1973) characterized by a reinforcing feedback loop involving poor education, unemployment, and susceptibility to conflicts and corruption (Fig. 5; Carter and Barrett 2006, Carpenter and Brock 2008).

In contrast to often dire social problems stemming from a turbulent history, the ecosystems of Transylvania are characterized by rich biodiversity and a highly heterogeneous farming landscape that provides a comprehensive set of ecosystem services, as shown by our results (Fig. 3), as well as in previous studies (Akeroyd and Page 2006, Hartel et al. 2014). After the collapse of communism, poor economic conditions prevented the widespread intensification of farming, and many local people continue to practice low-intensity, semi-subsistence agriculture (though often not by choice).

Our study shows that current stocks of both social and natural capital have arisen as a consequence of past system dynamics, and that current conditions and system dynamics provide both challenges and opportunities for the future. Current social dynamics largely present themselves as challenges, with a high risk that historical contingency will continue to cause the erosion of social capital and prevent economic development (as depicted in two of the scenarios; Fig. 6). In contrast, the high level of remaining natural capital provides a series of largely untapped opportunities, for example, for eco-tourism and nature conservation.

A unique opportunity for a sustainable development in southern Transylvania lies in the combination of the ongoing existence of traditional practices, knowledge, and fine-grained landscapes supporting high levels of biodiversity. Although communism and the emigration of ethnic Saxons have disrupted some of the traditional connections between nature and people in southern Transylvania, in comparison to most other parts of Europe, many genuine connections between people and nature have survived into the present. Southern Transylvania thus is one of Europe's last "biocultural refugia", defined by Barthel et al. (2013:1143) as "places that not only shelter species, but also carry knowledge and experiences about practical management of biodiversity and ecosystem services." Biocultural refugia potentially hold tremendous value for the future because they may help to generate visions and ideas for the reconnection of people and nature (Folke et al. 2011, Fischer et al. 2012b).

\section{External drivers set the general direction of regional development pathways}

External drivers fundamentally influence future developments in social-ecological systems through their interactions with local conditions (Cash et al. 2006). National and supra-national policy settings are particularly important in this context, both because they are highly influential and because they are amenable to being actively changed (and improved). In this case study, external policies and market settings were identified by local stakeholders as important drivers of a series of local changes, including the degree of forest exploitation, land abandonment, and emigration (Fig. 8).

In systems with explicit multi-level governance structures (such as in the EU), higher level institutions shape and constrain legislation, jurisdiction, and policy making at lower levels (Grabbe 2001, Bache 2010). In the EU, rural development, farmland biodiversity, and the ecosystem services flowing from farmland are strongly influenced by the Common Agricultural Policy (CAP; Henle et al. 2008, Plieninger et al. 2012). The CAP is a complex system of direct and indirect payments to rural communities. With regard to the study area, the CAP, its recent reform, and potentially more far-reaching reforms in the future, will greatly affect whether general development pathways are 
primarily pro-economy or pro-environment (as depicted in the scenarios; Fig. 6). To date, the CAP has favored economic interests over ecological concerns, although the latter have been addressed more explicitly in the most recent reform. Over a time horizon of several decades into the future, a more fundamental re-orientation toward the provision of public goods (including biodiversity and ecosystem services) is possible, and from a sustainability perspective, highly desirable.

In addition to the intent of a given policy, e.g., its emphasis on economic or environmental issues, the process of policy implementation will also change sustainability outcomes, and in the worst case, can even prevent the attainment of intended goals. The impact of exogenous drivers is also determined by the degree to which regional social-ecological systems are prepared for external changes, for example, in market regulations or legislation. In this respect, national governments need to be able to anticipate and buffer potentially negative impacts and to build societal capacities to capitalize on the opportunities provided by change. Both national and sub-national governments in Romania, for example, currently appear to favor economic growth in the farming sector over the support of smallholder farmers and nature conservation (Mikulcak et al. 2013). Potentially useful EU policies for rural development are not used to their full potential (Mikulcak et al. 2013), and weak governmental agencies and illenforced legislation support the exploitation of Romania's natural capital (Nichiforel and Schanz 2011, Knorn et al. 2012). In contrast to existing conditions, sustainable development could be positively influenced, for example, by more effective downward delegation of government authority to competent local actors (Folke et al. 2005, Lebel et al. 2006, Ostrom 2009), which might be more responsive to local needs and aspirations (Crook and Sverrisson 2001).

In summary, it is the combination of the intent of externally set policies and of their regional implementation that shapes the general direction of development pathways. Although much discussion tends to focus on policy intent (e.g., in the context of CAP reform), on-the-ground outcomes in multi-level governance systems are just as strongly influenced by the details of national and sub-national policy implementation.

\section{Local system properties can enhance or counteract the effects of external drivers}

Our results highlight that, despite the importance of external drivers (including higher level policy settings), local system properties such as overall levels of education, competent leadership, and presence of effective bridging organizations strongly influence sustainability outcomes. This is because local system properties can either facilitate or counteract the effects of external drivers. In the scenarios, such local system properties were captured by the second scenario axis (i.e., the ability of locals to capitalize on opportunities). Both the scenario narratives (Appendix 1) and scenario maps (Fig. 8) underscore that the same external policy settings can lead to fundamentally different development outcomes, depending on local conditions. For example, the trends toward abandonment and tourism development showed not only strong spatial variation within the region, but also rather distinct patterns between different scenarios (Fig. 8). This underscores that it is the interaction of external drivers with local system properties that shapes local development pathways.
The overall level of education was one of the key variables in the case study that was mentioned repeatedly in workshops as having a particularly large influence on local system dynamics (Fig. 5). Drèze and Sen (1996) argue that there is a direct relationship between literacy, the capability to understand rights, laws, and policies, and collective (political) action. A low education level hence reduces the capability of people to influence democratic processes and to hold (local) authorities accountable for their action or inaction (Agrawal and Ribot 1999), considerations that are particularly important in settings with high levels of corruption such as parts of Romania (Ristei 2010).

In addition to education, social networks and local leadership mediate how external drivers act on social-ecological systems. Social networks can increase the accountability of political elites (Lebel et al. 2006, Berkes 2009) and also enhance the adaptive capacity of vulnerable groups to transform a system configuration into a desired state (Carpenter et al. 2001, Holling 2001). Similarly, local leadership, for example, through mayors, teachers, or proactive citizens, can be an important source of clear, long-term visions and can encourage learning and innovation in local communities (Olsson et al. 2004, Black et al. 2011). Both social networks and leadership can be assisted by organizations that bridge gaps between citizens, civil society organizations, and government bodies at multiple levels. Such "bridging organizations" (Cash and Moser 2000, Olsson et al. 2007) serve to increase transparency in policy making and facilitate information transfer, both from higher to lower levels of administration and to other potentially interested parties (Olsson et al. 2007, Berkes 2009). For example, in Transylvania, some local organizations assist farmers in acquiring EU rural development funding and in marketing their products (Mikulcak et al. 2013), support the maintenance of cultural heritage, or inform people about legal issues around recently created conservation areas. Bridging organizations can also help to foster trust, lower the costs of conflict resolution and collaboration, and increase community cohesion, and thus, support the development of social capital (Folke et al. 2005). Commitment by leaders and bridging organizations to the community can also foster the development of rural enterprises of greater value such as specialty foods or agro-environmental tourism (Marsden and Smith 2005, Davidova et al. 2012).

\section{CONCLUSIONS}

Identifying pathways for sustainable development is an urgent need globally. We illustrated a holistic approach that combines existing methods to explore plausible future development pathways at the regional scale. At the heart of this approach is the recognition that biophysical and socioeconomic conditions fundamentally constrain and facilitate development pathways, that they influence one another, and that social-ecological conditions can vary within a given region. We applied this approach to a case study in central Romania, but we believe it could be applied similarly in other settings and could be particularly useful for spatially heterogeneous social-ecological systems facing high levels of uncertainty. Despite a need for global studies and global policy initiatives, in-depth regional-scale analyses deserve more attention by sustainability researchers than they currently receive (Wu 2013). On-the-ground sustainability outcomes arise from the interaction of higher level (exogenous) drivers and local-level (endogenous) system dynamics; therefore, it is important that local and regional data remain adequately 
valued within the scientific community (Lindenmayer and Likens 2011). The integration of findings from a variety of regional social-ecological case studies (e.g., via the Programme on Ecosystem Change and Society; Carpenter et al. 2012) can then be used to guide regional, national, and supra-national policy more effectively. Moreover, engaging with people at local to regional scales may be our best chance yet to trigger behavioral and institutional changes that are the backbone of sustainable development (Reid et al. 2009, Fischer et al. 2012a).

Responses to this article can be read online at: http://www.ecologyandsociety.org/issues/responses. php/6915

\section{Acknowledgments:}

We are indebted to all organizations and individuals from southern Transylvania for their engagement with our research. Particularly, we thank the Mihai Eminescu Trust for its support during the whole project. We are also grateful to all field assistants for help with data collection; J. Knorn, P. Griffiths, and M. Hampel for help with remote sensing analyses; and C. Scholtes for facilitating workshops. This work benefited from discussions with and comments by I. Fazey, G. Peterson, T. Gardner, and S. Carpenter. JH, DA, ID, JL, FM, $A M$, and $J F$ were funded through a Sofja-Kovalevskaja Award to $J F$, granted by the Alexander von Humboldt Foundation and sponsored by the German Ministry of Research and Education. TH was funded through a postdoctoral fellowship by the Alexander von Humboldt Foundation. TK gratefully acknowledges support by the European Commission (Integrated Project VOLANTE FP7ENV-2010-265104) and the Einstein Foundation, Berlin, Germany. The research reported in this paper contributes to the Programme on Ecosystem Change and Society (http://www.pecs-science.org).

\section{LITERATURE CITED}

Agrawal, A., and J. Ribot. 1999. Accountability in decentralization: a framework with South Asian and West African cases. Journal of Developing Areas 33(4):473-502.

Akeroyd, J. 2007. The historic countryside of the Saxon villages of southeast Transylvania. Fundaţia ADEPT, Saschiz, Mureș, Romania.

Akeroyd, J. R., and J. N. Page. 2011. Conservation of high nature value (HNV) grassland in a farmed landscape in Transylvania, Romania. Contributii Botanice 46:57-71.

Akeroyd, J. R., and N. Page. 2006. The Saxon villages of southern Transylvania: conserving biodiversity in a historic landscape. Pages 199-210 in D. Gafta and J. Akeroyd, editors. Nature Conservation. Springer, Berlin, Germany. http://dx.doi. org/10.1007/978-3-540-47229-2_21

Allison, H. E., and R. J. Hobbs. 2004. Resilience, adaptive capacity, and the "lock-in trap" of the western Australian agricultural region. Ecology and Society 9(1): 3. [online] URL: http://www.ecologyandsociety.org/vol9/iss1/art3/.

Anderson, B. J., P. R. Armsworth, F. Eigenbrod, C. D. Thomas, S. Gillings, A. Heinemeyer, D. B. Roy, and K. J. Gaston. 2009.
Spatial covariance between biodiversity and other ecosystem service priorities. Journal of Applied Ecology 46(4):888-896. http:// dx.doi.org/10.1111/j.1365-2664.2009.01666.x

Angelstam, P., L. Boresjo-Bronge, G. Mikusinski, U. Sporrong, and A. Wastfelt. 2003. Assessing village authenticity with satellite images: a method to identify intact cultural landscapes in Europe. Ambio 32(8):594-604. http://dx.doi.org/10.1579/0044-7447-32.8.594

Angelstam, P., M. Grodzynskyi, K. Andersson, R. Axelsson, M. Elbakidze, A. Khoroshev, I. Kruhlov, and V. Naumov. 2013. Measurement, collaborative learning and research for sustainable use of ecosystem services: landscape concepts and Europe as laboratory. Ambio 42(2):129-145. http://dx.doi.org/10.1007/ s13280-012-0368-0

Bache, I. 2010. Europeanization and multi-level governance: EU cohesion policy and pre-accession aid in southeast Europe. Southeast European and Black Sea Studies 10(1):1-12. http://dx. doi.org/10.1080/14683851003606739

Barthel, S., C. Crumley, and U. Svedin. 2013. Bio-cultural refugia - safeguarding diversity of practices for food security and biodiversity. Global Environmental Change 23(5):1142-1152. http://dx.doi.org/10.1016/j.gloenvcha.2013.05.001

Baumann, M., T. Kuemmerle, M. Elbakidze, M. Ozdogan, V. C. Radeloff, N. S. Keuler, A. V. Prishchepov, I. Kruhlov, and P. Hostert. 2011. Patterns and drivers of post-socialist farmland abandonment in western Ukraine. Land Use Policy 28(3):552-562. http://dx.doi.org/10.1016/j.landusepol.2010.11.003

Berkes, F. 2009. Evolution of co-management: role of knowledge generation, bridging organizations and social learning. Journal of Environmental Management 90(5):1692-1702. http://dx.doi. org/10.1016/j.jenvman.2008.12.001

Biggs, R., M. W. Diebel, D. Gilroy, A. M. Kamarainen, M. S. Kornis, N. D. Preston, J. E. Schmitz, C. K. Uejio, M. C. Van De Bogert, B. C. Weidel, P. C. West, D. P. M. Zaks, and S. R. Carpenter. 2010. Preparing for the future: teaching scenario planning at the graduate level. Frontiers in Ecology and the Environment 8(5):267-273. http://dx.doi.org/10.1890/080075

Black, S. A., J. J. Groombridge, and C. G. Jones. 2011. Leadership and conservation effectiveness: finding a better way to lead. Conservation Letters 4(5):329-339. http://dx.doi.org/10.1111/ j.1755-263X.2011.00184.X

Brown, G., and C. Raymond. 2007. The relationship between place attachment and landscape values: toward mapping place attachment. Applied Geography 27(2):89-111. http://dx.doi. org/10.1016/j.apgeog.2006.11.002

Carpenter, S., B. Walker, J. M. Anderies, and N. Abel. 2001. From metaphor to measurement: Resilience of what to what? Ecosystems 4(8):765-781. http://dx.doi.org/10.1007/s10021-001-0045-9

Carpenter, S. R., and W. A. Brock. 2008. Adaptive capacity and traps. Ecology and Society 13(2): 40. [online] URL: http://www. ecologyandsociety.org/vol13/iss2/art40/.

Carpenter, S. R., C. Folke, A. Norström, O. Olsson, L. Schultz, B. Agarwal, P. Balvanera, B. Campbell, J. C. Castilla, W. Cramer, R. DeFries, P. Eyzaguirre, T. P. Hughes, S. Polasky, Z. Sanusi, R. Scholes, and M. Spierenburg. 2012. Program on ecosystem change 
and society: an international research strategy for integrated social-ecological systems. Current Opinion in Environmental Sustainability 4(1):134-138. http://dx.doi.org/10.1016/j.cosust.2012.01.001

Carter, M. R., and C. B. Barrett. 2006. The economics of poverty traps and persistent poverty: an asset-based approach. Journal of Development Studies 42(2):178-199. http://dx.doi. org/10.1080/00220380500405261

Cash, D. W., W. N. Adger, F. Berkes, P. Garden, L. Lebel, P. Olsson, L. Pritchard, and O. Young. 2006. Scale and cross-scale dynamics: governance and information in a multilevel world. Ecology and Society 11(2): 8. [online] URL: http://www.ecologyandsociety. org/vol11/iss 2/art8/.

Cash, D. W., and S. C. Moser. 2000. Linking global and local scales: designing dynamic assessment and management processes. Global Environmental Change 10(2):109-120. http://dx.doi. org/10.1016/S0959-3780(00)00017-0

Costanza, R., S. van der Leeuw, K. Hibbard, S. Aulenbach, S. Brewer, M. Burek, S. Cornell, C. Crumley, J. Dearing, C. Folke, L. Graumlich, M. Hegmon, S. Heckbert, S. T. Jackson, I. Kubiszewski, V. Scarborough, P. Sinclair, S. Sörlin, and W. Steffen. 2012. Developing an integrated history and future of people on Earth (IHOPE). Current Opinion in Environmental Sustainability 4(1):106-114. http://dx.doi.org/10.1016/j.cosust.2012.01.010

Crook, R. C., and A. S. Sverrisson. 2001. Decentralisation and poverty-alleviation in developing countries: a comparative analysis or, is West Bengal unique? IDS Working Paper 130. Institute of Development Studies at the University of Sussex, Brighton, UK. [online] URL: https://www.ids.ac.uk/files/dmfile/Wp130.pdf.

Daconto, G., and L. N. Sherpa. 2010. Applying scenario planning to park and tourism management in Sagarmatha National Park, Khumbu, Nepal. Mountain Research and Development 30 (2):103-112. http://dx.doi.org/10.1659/MRD-JOURNAL-D-09-00047.1

Davidova, S., L. Fredriksson, M. Gorton, P. Mishev, and D. Petrovici. 2012. Subsistence farming, incomes, and agricultural livelihoods in the new member states of the European Union. Environment and Planning C: Government and Policy 30 (2):209-227. http://dx.doi.org/10.1068/c1195r

Dearing, J. A., A. K. Braimoh, A. Reenberg, B. L. Turner, and S. van der Leeuw. 2010. Complex land systems: the need for long time perspectives to assess their future. Ecology and Society 15 (4): 21. [online] URL: http://www.ecologyandsociety.org/vol15/ iss $4 / \operatorname{art} 21 /$

Dobre, A. M. 2009. The dynamics of Europeanisation and regionalisation: regional reform in Romania. Perspectives on European Politics and Society 10(2):181-194. http://dx.doi. org/10.1080/15705850902899222

Dreborg, K. H. 1996. Essence of backcasting. Futures 28 (9):813-828. http://dx.doi.org/10.1016/S0016-3287(96)00044-4

Drèze, J., and A. Sen. 1996. India: economic development and social opportunity. Oxford University Press, New Delhi, India.

Enfors, E. I., L. J. Gordon, G. D. Peterson, and D. Bossio. 2008. Making investments in dryland development work: participatory scenario planning in the Makanya catchment, Tanzania. Ecology and Society 13(2): 42. [online] URL: http://www.ecologyandsociety. org/vol13/iss2/art42/
Fischer, J., B. Brosi, G. C. Daily, P. R. Ehrlich, R. Goldman, J. Goldstein, D. B. Lindenmayer, A. D. Manning, H. A. Mooney, L. Pejchar, J. Ranganathan, and H. Tallis. 2008. Should agricultural policies encourage land sparing or wildlife-friendly farming? Frontiers in Ecology and the Environment 6(7):380-385. http://dx.doi.org/10.1890/070019

Fischer, J., R. Dyball, I. Fazey, C. Gross, S. Dovers, P. R. Ehrlich, R. J. Brulle, C. Christensen, and R. J. Borden. 2012a. Human behavior and sustainability. Frontiers in Ecology and the Environment 10(3):153-160. http://dx.doi.org/10.1890/110079

Fischer, J., T. Hartel, and T. Kuemmerle. 2012b. Conservation policy in traditional farming landscapes. Conservation Letters 5 (3):167-175. http://dx.doi.org/10.1111/j.1755-263X.2012.00227. $\underline{x}$

Folke, C. 2006. Resilience: the emergence of a perspective for social-ecological systems analyses. Global Environmental Change 16(3):253-267. http://dx.doi.org/10.1016/j.gloenvcha.2006.04.002

Folke, C., T. Hahn, P. Olsson, and J. Norberg. 2005. Adaptive governance of social-ecological systems. Annual Review of Environment and Resources 30:441-473. http://dx.doi.org/10.1146/ annurev.energy.30.050504.144511

Folke, C., Å. Jansson, J. Rockström, P. Olsson, S. R. Carpenter, F. S. Chapin III, A.-S. Crépin, G. Daily, K. Danell, J. Ebbesson, T. Elmqvist, V. Galaz, F. Moberg, M. Nilsson, H. Österblom, E. Ostrom, A. Persson, G. Peterson, S. Polasky, W. Steffen, B. Walker, and F. Westley. 2011. Reconnecting to the biosphere. Ambio 40 (7):719-738. http://dx.doi.org/10.1007/s13280-011-0184-y

Gibson, R. B. 2006. Sustainability assessment: basic components of a practical approach. Impact Assessment and Project Appraisal 24(3):170-182. http://dx.doi.org/10.3152/147154606781765147

Gorton, M., C. Hubbard, and L. Hubbard. 2009. The folly of European Union policy transfer: why the Common Agricultural Policy (CAP) does not fit central and eastern Europe. Regional Studies 43(10):1305-1317. http://dx.doi.org/10.1080/00343400802508802

Grabbe, H. 2001. How does Europeanization affect CEE governance? Conditionality, diffusion and diversity. Journal of European Public Policy 8(6):1013-1031. http://dx.doi. org/10.1080/13501760110098323

Hartel, T., J. Fischer, C. Câmpeanu, A. I. Milcu, J. Hanspach, and I. Fazey. 2014. The importance of ecosystem services for rural inhabitants in a changing cultural landscape in Romania. Ecology and Society 19(2): 42. http://dx.doi.org/10.5751/ES-06333-190242

Henle, K., D. Alard, J. Clitherow, P. Cobb, L. Firbank, T. Kull, D. McCracken, R. F. A. Moritz, J. Niemelä, M. Rebane, D. Wascher, A. Watt, and J. Young. 2008. Identifying and managing the conflicts between agriculture and biodiversity conservation in Europe - a review. Agriculture, Ecosystems and Environment 124 (1-2):60-71. http://dx.doi.org/10.1016/j.agee.2007.09.005

Henrichs, T., M. Zurek, B. Eickhout, K. Kok, C. RaudseppHearne, T. Ribeiro, D. van Vuuren, and A. Volkery. 2010. Scenario develoment and analysis for forward-looking ecosystem assessments. Pages 151-220 in N. Ash, H. Blanco, C. Brown, K. Garcia, T. Henrichs, N. Lucas, C. Raudsepp-Hearne, R. D. Simpson, R. Scholes, T. P. Tomich, B. Vira, and M. Zurek, editors. Ecosystems and human well-being: a manual for assessment 
practitioners. Island Press, Washington, D.C., USA. [online] URL: http://www.unep-wcmc.org/system/dataset_file fields/ files/000/000/109/original/EcosystemsHumanWellbeing.pdf?1398679213.

Holling, C. S. 2001. Understanding the complexity of economic, ecological, and social systems. Ecosystems 4(5):390-405. http:// dx.doi.org/10.1007/s10021-001-0101-5

Ioffe, G., T. Nefedova, and I. Zaslavsky. 2004. From spatial continuity to fragmentation: the case of Russian farming. Annals of the Association of American Geographers 94(4):913-943. http:// dx.doi.org/10.1111/j.1467-8306.2004.00441.x

Knorn, J., T. Kuemmerle, V. C. Radeloff, A. Szabo, M. Mindrescu, W. S. Keeton, I. Abrudan, P. Griffiths, V. Gancz, and P. Hostert. 2012. Forest restitution and protected area effectiveness in postsocialist Romania. Biological Conservation 146(1):204-212. http:// dx.doi.org/10.1016/j.biocon.2011.12.020

Kuemmerle, T., D. Müller, P. Griffiths, and M. Rusu. 2009. Land use change in southern Romania after the collapse of socialism. Regional Environmental Change 9(1):1-12. http://dx.doi. org/10.1007/s10113-008-0050-Z

Lebel, L., J. M. Anderies, B. Campbell, C. Folke, S. HatfieldDodds, T. P. Hughes, and J. Wilson. 2006. Governance and the capacity to manage resilience in regional social-ecological systems. Ecology and Society 11(1): 19. [online] URL: http://www. ecologyandsociety.org/vol11/iss1/art19/.

Lerman, Z., C. Csaki, and G. Feder. 2004. Evolving farm structures and land use patterns in former socialist countries. Quarterly Journal of International Agriculture 43(4):309-335.

Lindenmayer, D. B., and G. E. Likens. 2011. Losing the culture of ecology. Bulletin of the Ecological Society of America 92:245-246. http://dx.doi.org/10.1890/0012-9623-92.3.245

Liu, J. G., T. Dietz, S. R. Carpenter, M. Alberti, C. Folke, E. Moran, A. N. Pell, P. Deadman, T. Kratz, J. Lubchenco, E. Ostrom, Z. Ouyang, W. Provencher, C. L. Redman, S. H. Schneider, and W. W. Taylor. 2007. Complexity of coupled human and natural systems. Science 317(5844):1513-1516. http://dx.doi. org/10.1126/science.1144004

Marsden, T., and E. Smith. 2005. Ecological entrepreneurship: sustainable development in local communities through quality food production and local branding. Geoforum 36(4):440-451. http://dx.doi.org/10.1016/j.geoforum.2004.07.008

Meadows, D. H. 2009. Thinking in systems: a primer. Earthscan, London, UK.

Mikulcak, F., J. Newig, A. I. Milcu, T. Hartel, and J. Fischer. 2013. Integrating rural development and biodiversity conservation in central Romania. Environmental Conservation 40(2):129-137. http://dx.doi.org/10.1017/S0376892912000392

Nelson, E., G. Mendoza, J. Regetz, S. Polasky, H. Tallis, D. R. Cameron, K. M. A. Chan, G. C. Daily, J. Goldstein, P. M. Kareiva, E. Lonsdorf, R. Naidoo, T. H. Ricketts, and M. R. Shaw. 2009. Modeling multiple ecosystem services, biodiversity conservation, commodity production, and tradeoffs at landscape scales. Frontiers in Ecology and the Environment 7(1):4-11. http://dx.doi. org/10.1890/080023
Nichiforel, L., and H. Schanz. 2011. Property rights distribution and entrepreneurial rent-seeking in Romanian forestry: a perspective of private forest owners. European Journal of Forest Research 130(3):369-381. http://dx.doi.org/10.1007/s10342-009-0337-8

Olsson, P., C. Folke, V. Galaz, T. Hahn, and L. Schultz. 2007. Enhancing the fit through adaptive co-management: creating and maintaining bridging functions for matching scales in the Kristianstads Vattenrike Biosphere Reserve, Sweden. Ecology and Society 12(1): 28. [online] URL: http://www.ecologyandsociety. org/vol12/iss1/art28/.

Olsson, P., C. Folke, and T. Hahn. 2004. Social-ecological transformation for ecosystem management: the development of adaptive co-management of a wetland landscape in southern Sweden. Ecology and Society 9(4): 2. [online] URL: http://www. ecologyandsociety.org/vo19/iss4/art2/.

Ostrom, E. 2009. A general framework for analyzing sustainability of social-ecological systems. Science 325 (5939):419-422. http://dx.doi.org/10.1126/science.1172133

Palomo, I., B. Martín-López, C. López-Santiago, and C. Montes. 2011. Participatory scenario planning for protected areas management under the ecosystem services framework: the Doñana social-ecological system in southwestern Spain. Ecology and Society 16(1): 23. [online] URL: http://www.ecologyandsociety. org/vol16/iss1/art23/.

Peterson, G. D., G. S. Cumming, and S. R. Carpenter. 2003. Scenario planning: a tool for conservation in an uncertain world. Conservation Biology 17(2):358-366. http://dx.doi.org/10.1046/ j.1523-1739.2003.01491.x

Platt, J. 1973. Social traps. American Psychologist 28(8):642-651. http://dx.doi.org/10.1037/h0035723

Plieninger, T., C. Schleyer, H. Schaich, B. Ohnesorge, H. Gerdes, M. Hernández-Morcillo, and C. Bieling. 2012. Mainstreaming ecosystem services through reformed European agricultural policies. Conservation Letters 5(4):281-288. http://dx.doi. org/10.1111/j.1755-263X.2012.00240.X

Polasky, S., E. Nelson, E. Lonsdorf, P. Fackler, and A. Starfield. 2005. Conserving species in a working landscape: land use with biological and economic objectives. Ecological Applications 15 (4):1387-1401. http://dx.doi.org/10.1890/03-5423

Putnam, R., R. Leonardi, and R. Y. Nanetti. 1993. Making democracy work: civic traditions in modern Italy. Princeton University Press, Princeton, New Jersey, USA.

Qiu, J., and M. G. Turner. 2013. Spatial interactions among ecosystem services in an urbanizing agricultural watershed. Proceedings of the National Academy of Sciences 110 (29):12149-12154. http://dx.doi.org/10.1073/pnas.1310539110

Raudsepp-Hearne, C., G. D. Peterson, and E. M. Bennett. 2010. Ecosystem service bundles for analyzing tradeoffs in diverse landscapes. Proceedings of the National Academy of Sciences 107 (11):5242-5247. http://dx.doi.org/10.1073/pnas.0907284107

Reid, R. S., D. Nkedianye, M. Y. Said, D. Kaelo, M. Neselle, O. Makui, L. Onetu, S. Kiruswa, N. O. Kamuaro, P. Kristjanson, J. Ogutu, S. B. BurnSilver, M. J. Goldman, R. B. Boone, K. A. Galvin, N. M. Dickson, and W. C. Clark. 2009. Evolution of 
models to support community and policy action with science: balancing pastoral livelihoods and wildlife conservation in savannas of East Africa. Proceedings of the National Academy of Sciences Early Edition 1-6. http://dx.doi.org/10.1073/pnas.0900313106

Ristei, M. 2010. The politics of corruption: political will and the rule of law in post-communist Romania. Journal of Communist Studies and Transition Politics 26(3):341-362. http://dx.doi. org/10.1080/13523279.2010.496324

Rockström, J., W. Steffen, K. Noone, A. Persson, F. S. Chapin III, E. Lambin, T. M. Lenton, M. Scheffer, C. Folke, H. J. Schellnhuber, B. Nykvist, C. A. de Wit, T. Hughes, S. van der Leeuw, H. Rodhe, S. Sörlin, P. K. Snyder, R. Costanza, U. Svedin, M. Falkenmark, L. Karlberg, R. W. Corell, V. J. Fabry, J. Hansen, B. Walker, D. Liverman, K. Richardson, P. Crutzen, and J. Foley. 2009. Planetary boundaries: exploring the safe operating space for humanity. Ecology and Society 14(2): 32. [online] URL: http:// www.ecologyandsociety.org/vol14/iss2/art32/

Rounsevell, M. D. A., B. Pedroli, K.-H. Erb, M. Gramberger, A. G. Busck, H. Haberl, S. Kristensen, T. Kuemmerle, S. Lavorel, M. Lindner, H. Lotze-Campen, M. J. Metzger, D. Murray-Rust, A. Popp, M. Pérez-Soba, A. Reenberge, A. Vadineanu, P. H. Verburg, and B. Wolfslehner. 2012. Challenges for land system science. Land Use Policy 29(4):899-910. http://dx.doi.org/10.1016/ j.landusepol.2012.01.007

Rozelle, S., and J. F. M. Swinnen. 2004. Success and failure of reform: insights from the transition of agriculture. Journal of Economic Literature 42(2):404-456. http://dx.doi. org/10.1257/0022051041409048

Santelmann, M. V., D. White, K. Freemark, J. I. Nassauer, J. M. Eilers, K. B. Vaché, B. J. Danielson, R. C. Corry, M. E. Clark, S. Polasky, R. M. Cruse, J. Sifneos, H. Rustigian, C. Coiner, J. Wu, and D. Debinski. 2004. Assessing alternative futures for agriculture in Iowa, U.S.A. Landscape Ecology 19(4):357-374. http://dx.doi.org/10.1023/B:LAND.0000030459.43445.19

Schröter, D., W. Cramer, R. Leemans, I. C. Prentice, M. B. Araújo, N. W. Arnell, A. Bondeau, H. Bugmann, T. R. Carter, C. A. Gracia, A. C. de la Vega-Leinert, M. Erhard, F. Ewert, M. Glendining, J. I. House, S. Kankaanpää, R. J. T. Klein, S. Lavorel, M. Lindner, M. J. Metzger, J. Meyer, T. D. Mitchell, I. Reginster, M. Rounsevell, S. Sabaté, S. Sitch, B. Smith, J. Smith, P. Smith, M. T. Sykes, K. Thonicke, W. Thuiller, G. Tuck, S. Zaehle, and B. Zierl. 2005. Ecosystem service supply and vulnerability to global change in Europe. Science 310(5752):1333-1337. http://dx.doi. org/10.1126/science. 1115233

Spendzharova, A. B., and M. A. Vachudova. 2012. Catching up? Consolidating liberal democracy in Bulgaria and Romania after EU accession. West European Politics 35(1):39-58. http://dx.doi. org/10.1080/01402382.2012.631312

Walker, B., L. Gunderson, A. Kinzig, C. Folke, S. Carpenter, and L. Schultz. 2006. A handful of heuristics and some propositions for understanding resilience in social-ecological systems. Ecology and Society 11(1): 13. [online] URL: http://www.ecologyandsociety. org/vol11/iss1/art13/
Walker, B., and D. Salt. 2006. Resilience thinking: sustaining ecosystems and people in a changing world. Island Press, Washington, D.C., USA.

Wise, R. M., I. Fazey, M. Stafford Smith, S. E. Park, H. C. Eakin, E. R. M. Archer van Garderen, and B. Campbell. 2014. Reconceptualising adaptation to climate change as part of pathways of change and response. Global Environmental Change 28:325-336. http://dx.doi.org/10.1016/j.gloenvcha.2013.12.002

Wu, J. 2013. Landscape sustainability science: ecosystem services and human well-being in changing landscapes. Landscape Ecology 28(6):999-1023. http://dx.doi.org/10.1007/s10980-013-9894-9 


\section{Appendix 1 for Hanspach et al.: A holistic approach to studying social-ecological systems and its application to Southern Transylvania}

\section{Appendix Text A1.1}

\section{Local conditions}

We assessed local conditions in terms of natural capital and socio-economic conditions in the study area (Table A1.1). For an in-depth understanding, we initially analyzed a subset of 30 randomly selected villages (Fig. A1.1).

First, we characterized these villages with respect to their natural capital and statistically classified them into three groups. Villages in the first group (yellow in Fig. A1.2) were characterized by high proportions of forest, orchards, high carbon stocks, high species richness, high pollinator abundance and high scenic beauty. Villages in the second group (blue in Fig. A1.2) were characterized by a high proportion of arable land, and villages in the third group (red in Fig. A1.2) had high proportions of pasture. Based on this grouping, we concluded that village conditions could be effectively summarized by the amounts of the main land cover types (arable, pasture, forest).

Second, we described socio-economic conditions in the communes that the target villages belonged to. We used data from the commune level because socio-economic data were not available at the level of individual villages. Because some villages belonged to the same communes, this analysis was restricted to data from 22 communes. Again, we statistically classified the communes according to their characteristics and found two major groups of communes. Communes belonging to the first group (light blue in Fig. A1.3) were characterized by a high proportion of Romanians, few Hungarians, and relatively high emigration rates, whereas communes from the second group (orange in Fig. A1.3) had a high proportion of Hungarians, few Romanians, and relatively high immigration rates. Notably, the cluster analysis did not pick up the gradient that was described by the second ordination axis in Fig. A1.3. This second gradient related to unemployment rate, proportion of pupils and proportion of Roma. Because the plight and influence of ethnic Roma were frequently discussed by stakeholders as important socio-economic variables, we considered the proportion of Roma in a village in subsequent analyses.

In summary, we used the proportion of forest, arable land and pasture to summarize natural capital bundles characteristic of different villages; and we used the proportions of Hungarians and Roma to summarize socio-economic conditions of different villages. In both cases, these variables were derived from detailed data obtained for a subset of villages, but 
the resulting general variables were subsequently used to characterize conditions in all villages throughout the study area.

\section{Full scenario narratives}

\section{Scenario 1: "Prosperity through growth"}

European Union (EU) incentives and global markets have created a favorable business environment. Demand is high for conventionally produced agricultural and forest products. National policies are strongly favoring economic development, including in rural areas.

Drawing on the natural capital available, local entrepreneurs (and a small number of foreigners) are using this institutional setting to take advantage of business opportunities, and partnerships between Western European and Romanian companies are common. Both farmland and forests are being used intensively wherever the landscape allows it, including the use of fertilizers and irrigation of farmland. The scenic beauty of the landscape suffers as a result, but plenty of money is flowing from commodities such as fuel and food crops, as well as wood.

Although the incomes of most people are modest compared to those running the new businesses, economic development has improved the region's overall material well-being. The education system also has improved, and there are many opportunities to obtain vocational training.

Tourism is centered on cultural heritage sites and newly emerging fun parks. Neither the natural environment nor traditional festivals contribute significantly to the tourism sector.

Land use intensification has caused the loss of biodiversity throughout the landscape, including the local extinction of several species of conservation concern. The water from local fountains is no longer safe for consumption, but people are largely indifferent to this because, unlike in the past, their houses are now connected to running water. Intensive forestry has left some hilltops without trees. As a result, runoff events are more intense than they used to be, causing the erosion of slopes and occasional floods.

Conflicts in the communities are less pronounced than earlier in the millennium, largely because fewer people suffer from poverty. Although individualism is more notable than in the past, community spirit has increased in many villages due to improved material conditions. Corruption levels have decreased, but doubts remain about the inner workings of some of the most successful farm businesses. 
In aggregate terms, people in the region are better off than at the beginning of the millennium - but improvements to aggregate welfare have not reached everybody equally, and natural capital has paid a high price.

\section{Scenario 2: "Our land, their wealth"}

The business environment in Europe is very favorable: There is high demand both for agricultural and forest products, as well as for tourism. However, local conditions in Southern Transylvania are in stark contrast to the larger-scale context. For decades, Southern Transylvania has been trapped in conditions of community fragmentation, poor infrastructure, and corruption.

Owing to low social capital and poverty, the people in Southern Transylvania are unable to capitalize on the opportunities provided by global market settings. Both national and local governments are failing to support the development of markets and necessary infrastructure that would benefit smallholder farmers. Yet, the region's natural capital does not go entirely unnoticed: Romanians from outside Transylvania and foreigners increasingly move into the area to set up large businesses focusing on forestry and agriculture. Where regulations stand in the way of development, corruption usually finds a way around these obstacles - as a result, forest exploitation is now characterized by intensive clearcuts, and industrial-style farms controlled by foreign companies occupy most of the larger valleys (referred to as "Iand grabbing" by some locals).

In some remote villages, land use has not intensified. In some locations, subsistence agriculture continues to exist, and some locals have found viable economic niches to produce specialty products such as goat cheese and honey. In other locations, much of the land has been abandoned. Regrowth forest is expanding into these areas.

Tourism has mostly disappeared, or it is controlled by foreigners. Most of the cultural heritage is in poor shape, and natural heritage is rapidly deteriorating. Whoever is capable of leaving the region - even for poorly paid seasonal work in other countries - does not hesitate to go. The people remaining are mainly the elderly and the very poor, including many Roma. Community spirit is declining and many traditional cultural values are being lost.

While ecosystems were once rich in biodiversity, many species have declined over the last few decades. Only the most remote villages still feature the species that Transylvania once was famous for among naturalists. With deteriorating ecosystem integrity, many of nature's services have also taken a heavy toll - for example, fountain water is no longer safe for 
consumption, some of the steeper logged areas are rapidly eroding, and intense runoff after heavy rainfall occasionally causes flooding.

Overall, local people have suffered and the traditional landscape character has been lost. Only few individuals, mostly from outside the local area, have benefited from the developments.

\section{Scenario 3: "Balance brings beauty"}

Demand for environmentally friendly practices was already high in Western Europe, when in 2020, France narrowly avoided a major nuclear accident. This event precipitated rapid political changes throughout the European Union (EU). Social justice and ecological sustainability were adopted as guiding principles underpinning all EU regulations. Unlike its predecessor, the latest reform of the Common Agricultural Policy brought about fundamental changes, and is considered worldwide as a milestone towards sustainable development. Subsidies are now strongly focused on organic farming, available only to associations of farmers who can demonstrate a holistic, landscape-scale vision for sustainable resource use.

Romania's education system improved substantially over the past few decades, enabling many locals in southern Transylvania to access the new EU subsidies for sustainable farming. Farms continue to be relatively small, but almost all farmers are now part of agricultural associations and practice modern organic farming, growing a variety of crops.

The forestry sector has also changed. Demand for wood products is high, but the majority of Romania's forestry sector is based on sustainable, low-intensity harvesting. Moreover, forest regrowth rates have increased substantially. While few forested areas remain untouched, Romania's forest estate is managed according to the best available science.

Farmland and forest biodiversity initially declined when land use was upgraded to modern organic practices, but the losses were relatively minor. Water from the fountains is just as clean as it was decades ago, and continues to be favored as the cheapest source of drinking water in many villages.

A vibrant rural tourism industry has developed in the most scenic villages. Guesthouses are common, as are cafes and traditional festivals. Local people are proud that their cultural and natural heritage is attracting tourists from all over Europe.

Few people in the region are rich in monetary terms, but hardly anybody is suffering from poverty. People coped well with the recent drought, and are largely immune to the fluctuations in agricultural commodity prices that recently shook many farmers in Western 
Europe. Ethnic divides have all but disappeared, partly aided by common visits by foreigners and increasing openness towards different cultures. A healthy service industry is developing in addition to the most important income sectors, namely agriculture, forestry and tourism. While many young locals leave the region for a while, many of them come back because they are attracted by the lifestyle and scenic beauty in their home region.

\section{Scenario 4: "Missed opportunity"}

The latest reform of the Common Agricultural Policy provides major subsidies for organic farming across Europe. Minimum size requirements of agricultural parcels can be met by forming farmer associations.

However, only few communities are able to capitalize on this opportunity, despite all relevant information being readily available via standard technologies such as the internet. Many villages are caught up in a vicious cycle of poverty, conflict and corruption. In these villages, a long history of mistrust, conflict, and crime stands in the way of the formation of farmer associations.

Yet, the productive soils and ready availability of cheap labor do not go unnoticed internationally. Increasingly, western European entrepreneurs see opportunities in being able to buy Transylvanian land and start large organic farm businesses, drawing on substantial EU subsidies in the process. These farms create some employment opportunities for local villagers, but primarily favor skilled workers who are able to operate modern machinery. To meet this demand for skilled labor, vocational training opportunities have increased.

Under new EU regulations, large parts of the forest estate are formally protected.

Commercial forestry operations are led by a small number of international companies. Antilogging regulations are being actively enforced in large parts of Southern Transylvania, but some illegal logging continues - driven by corrupt local governments turning a blind eye to illegal operations, and by locals who prefer to take a risk rather than pay for their firewood.

The population of Southern Transylvania is declining. Many remote villages are almost entirely abandoned, or comprise only poor households practicing subsistence agriculture. Around abandoned villages, pastures are overgrowing and turning into regrowth forest.

Farmland biodiversity is declining where large organic farms have simplified the landscape. However, in less suitable areas, subsistence agriculture remains and continues to provide a stronghold for farmland species that are threatened with extinction elsewhere in Europe. If it was not for the free services provided by nature - clean water and plenty of food - many 
Transylvanians would be in serious trouble. As it stands, many are poor, but not lacking the essentials they need for survival. 


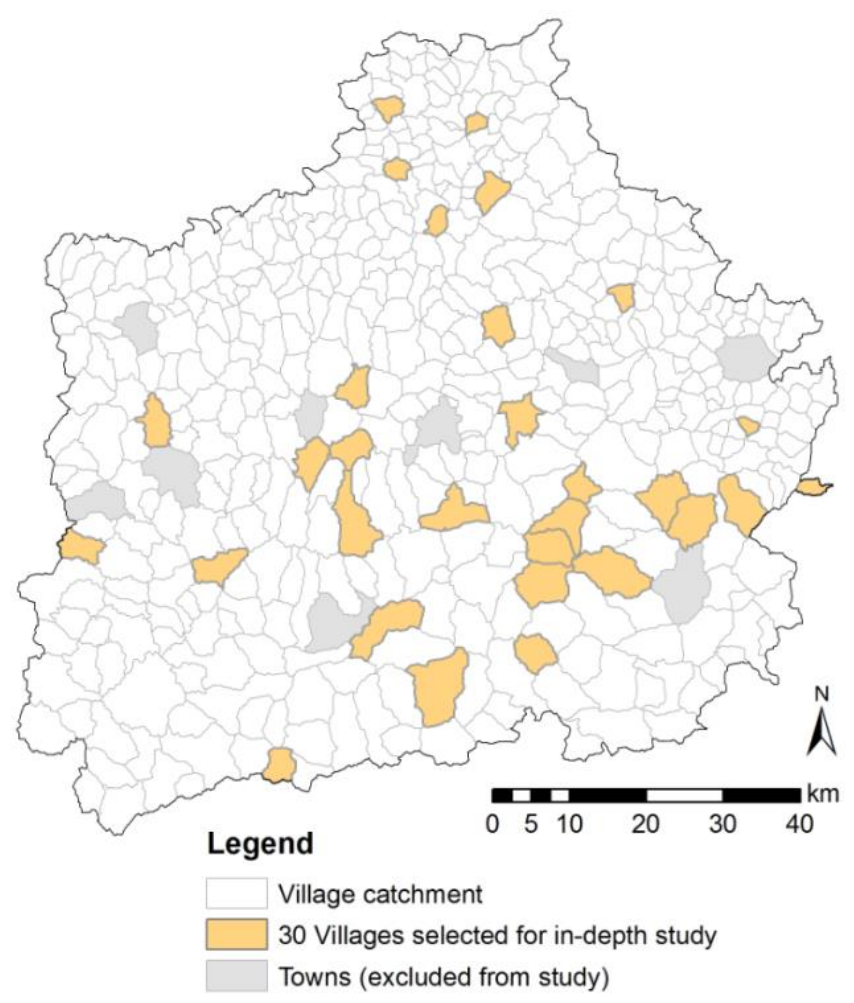

Appendix Fig. A1.1. A subset of 30 villages was selected for in-depth characterization of local village conditions. Villages were chosen randomly within pre-defined strata relating to their protection status under EU Natura 2000 regulations and terrain ruggedness. 


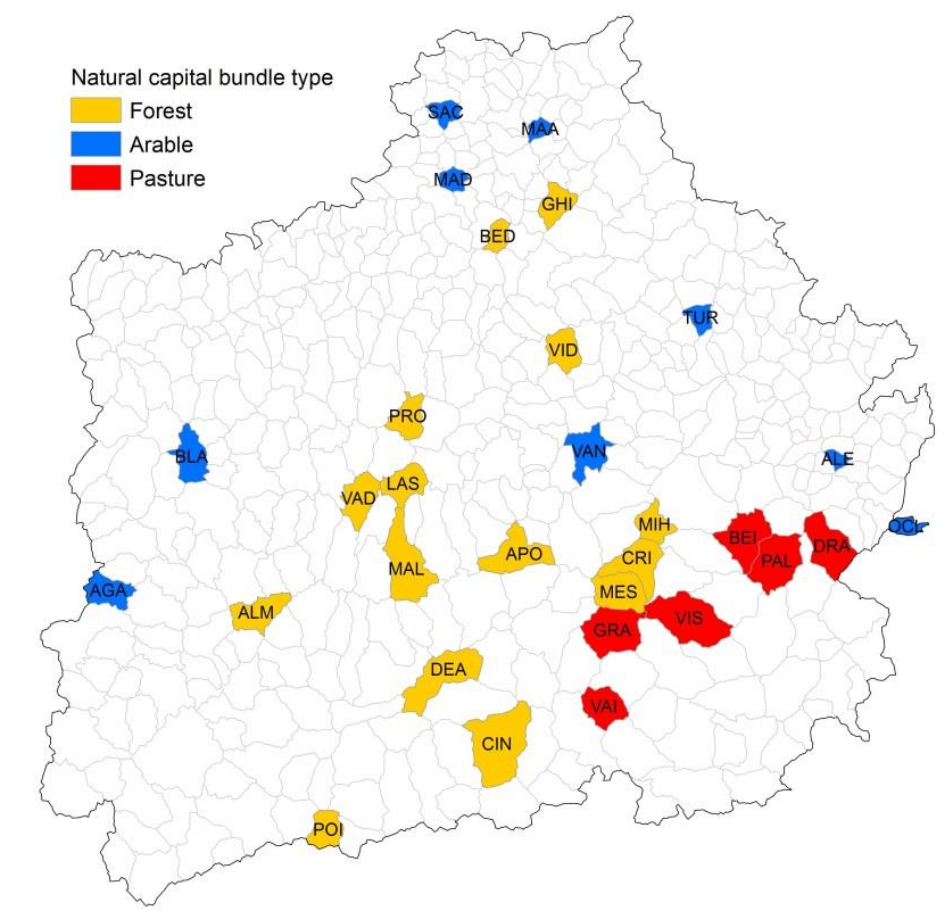

Appendix Fig. A1.2. Statistical classification of the 30 focal villages according to their natural capital assets. The three village types (forest - yellow, arable - blue, pasture - red) were derived from agglomerative cluster analysis (see Fig. 3). 


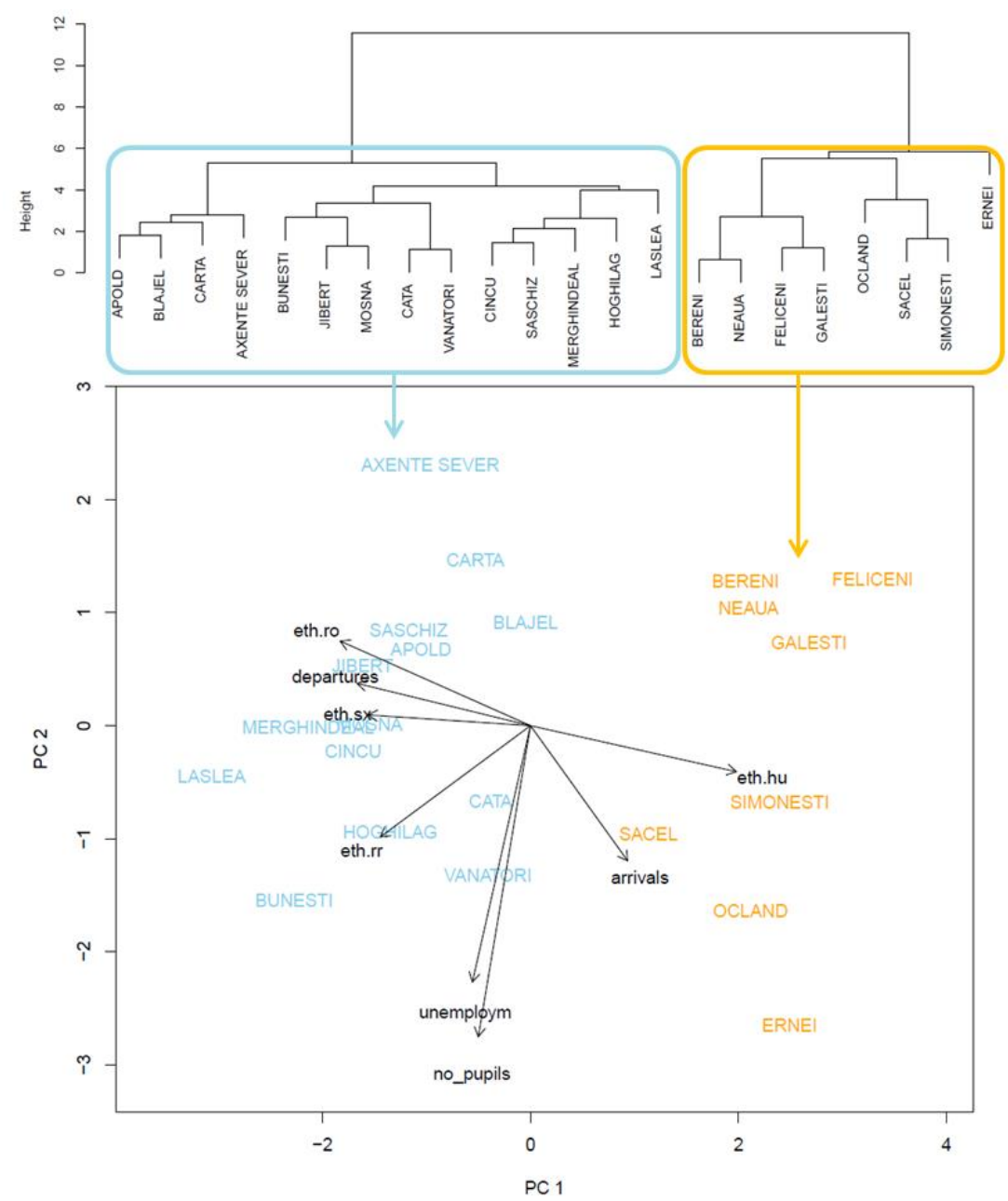

Appendix Fig. A1.3. Structure of demographic and socio-economic data of the 22 communes in which the 30 focal villages were located. The figure shows the results of an agglomerative cluster analysis (upper panel; Wards method on Euclidean distances; agglomerative coefficient: 0.83 ) and a centered principal components analysis (lower panel; all variables scaled; explained variance of the first axis: $46 \%$; and of the second axis: $19 \%)$. Two main groups of villages, relating to dominant ethnicity, are apparent. (Abbreviations: eth.ro proportion of Romanians [\%]; eth.hu - proportion of Hungarians [\%]; eth.rr - proportion of Roma [\%]; eth.sx - proportion of Saxons [\%]; unemploym - unemployment rate; no_pupils number of pupils; arrivals - number of people arriving relative to total number of people in a commune; departures - number of people departing relative to total number of people in a commune) 
Appendix Table A1.1. List and detailed description of variables used to describe local characteristics. Asterisks indicate variables that were assessed for the whole study area. All other variables were additionally used for an in-depth description of the random subset of 30 villages.

\begin{tabular}{|c|c|}
\hline $\begin{array}{l}\text { Ecological } \\
\text { variables }\end{array}$ & Description \\
\hline Arable* & $\begin{array}{l}\text { Proportion of arable land (all non-permanent crops according to Corine } 2006 \text { Land } \\
\text { Cover Map (EEA 2006)) relative to total village area as a proxy for the potential to } \\
\text { generate food and other agricultural products }\end{array}$ \\
\hline Pasture* & $\begin{array}{l}\text { Proportion of pastures according to Corine } 2006 \text { relative to total village area as a } \\
\text { proxy for the potential to generate milk, cheese, meat, and wool }\end{array}$ \\
\hline Forest* & $\begin{array}{l}\text { Proportion of forest according to Corine } 2006 \text { relative to total village area as a } \\
\text { proxy for the potential to obtain timber, firewood and non-timber products, but } \\
\text { also non-provisioning services like flood protection and water purification }\end{array}$ \\
\hline Orchards & $\begin{array}{l}\text { Proportion of orchards according to Corine } 2006 \text { relative to total village area as a } \\
\text { proxy for the potential to grow fruit }\end{array}$ \\
\hline Scenic beauty & $\begin{array}{l}\text { Expressed as a village ranking based on a scoring system that was informed by our } \\
\text { personal experience in the field and stakeholder discussions. The score of a given } \\
\text { village was the sum of individual scores derived from forest cover (village belongs } \\
\text { to the lower tercile, i.e. has low forest cover: }-1 \text {; village belongs to the upper } \\
\text { tercile, i.e. has a high forest cover: }+1 \text { ), terrain ruggedness (lower tercile: }-1 \text {, upper } \\
\text { tercile: }+1 \text { ), landscape heterogeneity (lower tercile: }-1 \text {, upper tercile: }+1) \text {, presence } \\
\text { of fortified churches or castles }(+1) \text { and the presence of major roads }(-1) \text {. }\end{array}$ \\
\hline Hunting & $\begin{array}{l}\text { To estimate utility as a hunting area, we extracted the estimated population sizes } \\
\text { of red deer, roe deer, boar and hare between } 2001 \text { and } 2010 \text { from official sources } \\
\text { (http://www.mmediu.ro/paduri/vanatoare.htm), normalized the data to unit area } \\
\text { and ranked the villages according to the relative total count of hunted individuals } \\
\text { per unit area }\end{array}$ \\
\hline Carbon stocks & $\begin{array}{l}\text { Carbon stocks were derived by calculating an average amount of carbon } \\
\text { (aboveground, belowground, soil) per ha and per land cover type (arable, pasture, } \\
\text { forest) and subsequently calculating the total carbon stock per catchment. } \\
\text { Information on carbon concentration was derived from the IPCC (IPCC 2006). }\end{array}$ \\
\hline $\begin{array}{l}\text { Farmland } \\
\text { biodiversity }\end{array}$ & $\begin{array}{l}\text { Farmland biodiversity was estimated as the number of plant, butterfly, and bird } \\
\text { species in } 1 \text { ha grid cells in the farmland of each village catchment based on field } \\
\text { data, and was then averaged to the village catchment. The estimate per grid cell } \\
\text { was based on field surveys in } 120 \text { circular } 1 \text { ha sites ( } 2 \text { sites in pasture and } 2 \text { in } \\
\text { arable in each of the } 30 \text { villages) during spring and summer of } 2012 \text {. Within a given } \\
\text { village catchment, survey sites were chosen using stratified random selection. } \\
\text { Stratification was performed by fully covering gradients in landscape heterogeneity } \\
\text { (measured as the variation in the panchromatic channel of SPOT } 5 \text { satellite imagery }\end{array}$ \\
\hline
\end{tabular}




\begin{tabular}{|c|c|}
\hline & $\begin{array}{l}\text { (CNES 2007, Distribution Spot Image SA) in a } 1 \text { ha circle) and amount of woody } \\
\text { vegetation (derived by a supervised classifications of the monochromatic channels } \\
\text { of SPOT } 5 \text { data using a support vector machine algorithm, Huang et al. 2002). Plant } \\
\text { surveys were conducted in spring/summer } 2012 \text { using eight randomly selected } 1 \\
\mathrm{~m}^{2} \text { squares within each } 1 \text { ha site, and noting all present species. Butterfly richness } \\
\text { was estimated by conducting four standard Pollard walks (Pollard \& Yates 1993) of } \\
50 \mathrm{~m} \text { length within a given site, repeated at four different times during } \\
\text { spring/summer 2012. Bird richness was estimated by conducting three } 10 \text { min } \\
\text { point counts within each site in spring 2012. All singing males were recorded. The } \\
\text { richness estimates thus obtained for each of } 120 \text { sites for each group were } \\
\text { modelled in response to percent woody vegetation and heterogeneity within the } \\
\text { site as predictor variables in linear models (using linear and quadratic terms as } \\
\text { predictors). Based on these models we predicted the richness of the different } \\
\text { groups for the whole farmland area of the catchments, excluding areas outside of } \\
\text { the calibration range of the independent variables. We calculated the averaged } \\
\text { richness for each taxonomic group for each of the } 30 \text { village catchments. Finally, to } \\
\text { visualize the relative level of farmland biodiversity in a given village, we ranked } \\
\text { villages according to their average rank of the richness in each of the three groups. }\end{array}$ \\
\hline & $\begin{array}{l}\text { Pollinator abundance was assessed by counting pollinating insects in } 2 \mathrm{~m} \text { wide and } \\
200 \mathrm{~m} \text { long transects within a subset of } 76 \text { of the } 1201 \text { ha sites described above. } \\
\text { Each site was sampled three times for } 20 \text { min periods between May and July } 2012 \text {. } \\
\text { The total number of individuals from all relevant groups of pollinators (honeybees, } \\
\text { wild bees, bumblebees, hoverflies, and butterflies) was modelled as for } \\
\text { biodiversity to obtain an index of pollinator abundance for each village catchment. }\end{array}$ \\
\hline $\begin{array}{l}\text { Social } \\
\text { variables }\end{array}$ & Description \\
\hline Ethnic groups* & $\begin{array}{l}\text { Proportion of the main ethnic groups (Romanians, Hungarians, Roma and Saxons) } \\
\text { relative to the total population in a given commune in } 2010 \text { as derived from the } \\
\text { National Institute for Statistics (Institutul Național de Statistică; data received } 6 \\
\text { February 2012). }\end{array}$ \\
\hline $\begin{array}{l}\text { Unemployment } \\
\text { rate }\end{array}$ & $\begin{array}{l}\text { Proportion of people unemployed relative to the total population in a given } \\
\text { commune in } 2010 \text { (source: see ethnic groups) }\end{array}$ \\
\hline Arrivals & $\begin{array}{l}\text { Proportion of people arriving in a given commune between } 1995 \text { and } 2005 \text { relative } \\
\text { to the total population in a given commune in } 2010 \text { (source same as ethnic groups) }\end{array}$ \\
\hline Departures & $\begin{array}{l}\text { Proportion of people departing in a given commune between } 2005 \text { and } 2010 \\
\text { relative to the total population in a given commune in } 2010 \text { (source: see ethnic } \\
\text { groups) }\end{array}$ \\
\hline Pupils & $\begin{array}{l}\text { Number of registered pupils relative to the total population size in a given } \\
\text { commune in } 2010 \text { (source: see ethnic groups) }\end{array}$ \\
\hline $\begin{array}{l}\text { Additional } \\
\text { variables }\end{array}$ & Description \\
\hline Village area* & accordıng to Corıne 2006 Land Cover IV \\
\hline
\end{tabular}




\begin{tabular}{|l|l|}
\hline & 2006) \\
\hline Isolation* & $\begin{array}{l}\text { Isolation from the nearest town was estimated as the travel time by car to the next } \\
\text { town with }>20000 \text { inhabitants, distinguishing between four different types of road } \\
\text { for all villages in the study area }\end{array}$ \\
\hline Ruggedness* & $\begin{array}{l}\text { Terrain ruggedness was calculated as the standard deviation of altitude from } \\
\text { ASTER GDEM v2 within a given catchment }\end{array}$ \\
\hline
\end{tabular}

Appendix Table A1.2. Scores describing how variables of regional system dynamics relate to certain local village condition. Values represent reasonable and consistent trends that were mentioned in the stakeholder workshops.

\begin{tabular}{|c|c|c|c|c|c|c|c|c|c|}
\hline Driver & $\begin{array}{l}\text { Description } \\
\text { of driver }\end{array}$ & $\begin{array}{l}\text { Intensi- } \\
\text { fication }\end{array}$ & $\begin{array}{l}\text { Abandon- } \\
\text { ment }\end{array}$ & $\begin{array}{l}\text { Forest } \\
\text { exploi- } \\
\text { tation }\end{array}$ & Tourism & $\begin{array}{l}\text { Local } \\
\text { economy }\end{array}$ & $\begin{array}{l}\text { Social } \\
\text { capital }\end{array}$ & $\begin{array}{l}\text { Emi- } \\
\text { gration }\end{array}$ & $\begin{array}{l}\text { Influence } \\
\text { of } \\
\text { foreigners }\end{array}$ \\
\hline $\begin{array}{l}\text { Proportion of } \\
\text { Roma }\end{array}$ & $\begin{array}{l}\text { high: upper } \\
\text { third }\end{array}$ & & +1 & +1 & & -1 & -1 & & \\
\hline $\begin{array}{l}\text { Proportion of } \\
\text { Hungarians }\end{array}$ & $\begin{array}{l}\text { high: upper } \\
\text { third }\end{array}$ & +1 & & & & +1 & +1 & & \\
\hline \multirow{3}{*}{ Isolation } & high & -1 & +1 & & 0 & -1 & +1 & & \\
\hline & medium & 0 & 0 & & +1 & 0 & +0.5 & & \\
\hline & low & +1 & -1 & & 0 & +1 & 0 & & \\
\hline \multirow{3}{*}{ Village size } & small & -1 & +1 & 0 & +1 & -1 & +1 & +1 & \\
\hline & medium & 0 & 0 & +0.5 & +0.5 & 0 & +0.5 & +0.5 & \\
\hline & large & +1 & -1 & +1 & 0 & +1 & 0 & 0 & \\
\hline \multirow{3}{*}{ Ruggedness } & low & +1 & -1 & & 0 & & 0 & & \\
\hline & medium & 0 & 0 & & +0.5 & & +0.5 & & \\
\hline & high & -1 & +1 & & +1 & & +1 & & \\
\hline $\begin{array}{l}\text { Proportion of } \\
\text { arable land }\end{array}$ & $\begin{array}{l}\text { high: upper } \\
\text { third }\end{array}$ & +1 & & & & +1 & & & +1 \\
\hline $\begin{array}{l}\text { Proportion of } \\
\text { pasture land }\end{array}$ & $\begin{array}{l}\text { high: upper } \\
\text { third }\end{array}$ & +1 & & & +1 & & & & \\
\hline $\begin{array}{l}\text { Proportion of } \\
\text { forest }\end{array}$ & $\begin{array}{l}\text { high: upper } \\
\text { third }\end{array}$ & & & +1 & +1 & & & & \\
\hline
\end{tabular}


Appendix Table A1.3. Scores describing how trends in variables of regional system dynamics are expected to change under the four different scenarios. Values are based on the relative changes as described in the scenario narratives. Possible changes are: strong dampening ($3)$; intermediate dampening (-2); weak dampening (-1); no change (0); weak amplification $(+1)$; intermediate amplification (+2); strong amplification (+3).

\begin{tabular}{|l|c|c|c|c|c|c|c|c|}
\hline Scenarios & Intensification & Abandonment & $\begin{array}{l}\text { Forest } \\
\text { exploitation }\end{array}$ & Tourism & $\begin{array}{l}\text { Local } \\
\text { economy }\end{array}$ & $\begin{array}{l}\text { Social } \\
\text { capital }\end{array}$ & Emigration & $\begin{array}{l}\text { Influence of } \\
\text { foreigners }\end{array}$ \\
\hline $\begin{array}{l}\text { Prosperity } \\
\text { through growth }\end{array}$ & +3 & -2 & +2 & +1 & +3 & +1 & +1 & 0 \\
\hline $\begin{array}{l}\text { Our land, their } \\
\text { wealth }\end{array}$ & +3 & +1 & +3 & -2 & 0 & -1 & +3 & +3 \\
\hline $\begin{array}{l}\text { Balance brings } \\
\text { beauty }\end{array}$ & +2 & -1 & -1 & +2 & +1 & +3 & -2 & 0 \\
\hline $\begin{array}{l}\text { Missed } \\
\text { opportunity }\end{array}$ & +1 & +2 & +1 & -1 & 0 & -1 & +2 & +1 \\
\hline
\end{tabular}

\section{References}

EEA. 2006. Corine land cover 2006 - A seamless vector database. Copenhagen, European Environment Agency.

Huang, C., L. S. Davis, and J. R. G. Townshend. 2002. An assessment of support vector machines for land cover classification. International Journal of Remote Sensing 23(4):725749.

IPCC. 2006. IPCC Guidelines for National Greenhouse Gas Inventories, Volume 4: Agriculture, Forestry and Other Land Use. Prepared by the National Greenhouse Gas Inventories Programme. in H. Eggleston, L. Buendia, K. Miwa, T. Ngara, and K. Tanabe, editors. Hayama, Japan, Institute for Global Environmental Strategies (IGES).

Pollard, E., and T. J. Yates. 1993. Monitoring butterflies for ecology and conservation : the British butterfly monitoring scheme. London, Chapman \& Hall. 